pag

Business School

WORKING PAPER SERIES

Working Paper 2014-159
Do global factors impact BRICS stock markets? A quantile regression approach

Walid Mensi

Shawkat Hammoudeh

Juan Carlos Reboredo

Duc Khuong Nguyen

http://www.ipag.fr/fr/accueil/la-recherche/publications-WP.html

IPAG Business School

184, Boulevard Saint-Germain

75006 Paris

France 


\title{
Do global factors impact BRICS stock markets? A quantile re- gression approach
}

\author{
Walid Mensi ${ }^{\mathrm{a}}$, Shawkat Hammoudeh ${ }^{\mathrm{b}}$, Juan Carlos Reboredo ${ }^{\mathrm{c}}$, Duc Khuong Nguyen ${ }^{\mathrm{d}, *}$ \\ ${ }^{a}$ Department of Finance and Accounting, Faculty of Management and Economic Sciences of Tunis, \\ El Manar University, B.P. 248, C.P. 2092, Tunis Cedex, Tunisia \\ Emails: walid.mensi@fsegt.rnu.tn, \\ ${ }^{b}$ Lebow College of Business, Drexel University, Philadelphia, PA 19104-2875, United States \\ Email: hammousm@drexel.edu \\ ${ }^{\mathrm{c}}$ Universidade de Santiago de Compostela, Departamento de Fundamentos del Análisis Económico, \\ Avda. Xoán XXIII, s/n, 15782 Santiago de Compostela, Spain \\ Email: juancarlos.reboredo@usc.es \\ ${ }^{d}$ IPAG Lab, IPAG Business School, 184 Boulevard Saint-Germain, 75006 Paris, France | Phone: \\ +33(0)153633600 Fax: +33(0)145444046 \\ Email: duc.nguyen@ipag.fr \\ *Corresponding author
}

\begin{abstract}
This paper examines the dependence structure between the emerging stock markets of the BRICS countries (Brazil, Russia, India, China and South Africa) and influential global factors (the S\&P 500 index, the commodity markets, the global stock market uncertainty and the US economic policy uncertainty). Using the quantile regression approach, our results for the period from September 1997 to September 2013 show that the BRICS stock markets exhibit asymmetric dependence with the global stock market and this dependence has not changed since the onset of the recent global financial crisis. Moreover, oil prices display a symmetric tail independence with all those BRICS markets (except that of South Africa), even though the dependence between oil and BRICS markets significantly increased with the onset of the financial crisis. The gold price returns co-move with those of the BRICS markets at both the upper and lower tails (except for Russia and China) but the degree of comovement has decreased since the crisis. Finally, the stock market uncertainty (VIX) is found to drive the stock returns in a bear market but this relationship is insignificant in a bull market. On the other hand, the economic policy uncertainty has no impact on the BRICS stock markets both before and since the onset of the financial crisis. These results have implications for international investors in terms of risk management which should vary according to changes in the economic and financial global factors.
\end{abstract}

JEL classification: G14; G15

Keywords: Asymmetric dependence; global factors; BRICS; global financial crisis; quantile regression. 


\section{Introduction}

The economies of the BRICS countries (Brazil, Russia, India, China and South Africa) have grown at a rapid pace and are becoming increasingly more integrated with the most developed economies in terms of trade and investment. They account for more than a quarter of the world's land area, more than 40 percent of the world's population and about 15 percent of global GDP. Goldman Sachs expects the total nominal GDP for the four BRIC countries (excluding South Africa) to reach $\$ 128$ trillion in 2050 , compared to $\$ 66$ trillion for the G7 countries at that time. The current and potential growth of the BRICS countries also has important implications for the capitalization of their stock markets as well as for their financial dependence with other stock markets. The four BRIC countries are expected to account for $41 \%$ of the world's stock market capitalization by 2030 , when China is expected to overtake the United States in equity market capitalization, thus becoming the largest equity market in the world. Recently, several studies including Liu et al. (2013) and Zhang et al. (2013) among others, have added South Africa into the BRIC group as this country has also a fast-growing economy, experiences rapid financial market development and sophistication, and is globally recognized as a source possessing sophisticated professional services and financial expertise. South Africa is also known as one of the world's largest producer of some strategic commodities (e.g., gold, platinum, and chrome) which are a critical resource to support domestic and global economic growth. Thus, the presence of South Africa in the BRICS group provides opportunities to establish a dedicated investment strategy in terms of economic diversification opportunities.

In this article, we examine how global economic factors such as changes in the global stock market, commodity prices, the U.S. economic policy uncertainty, and the stock market uncertainty (as defined by CBOE VIX) influence the performance of BRICS stock markets. Our analysis is motivated by the fact that the BRICS countries are the major recipients of 
global investment flows and are among the main global consumers of commodities. Therefore, changes in the global economic factors could be a channel through which fluctuations in the world's economic and financial conditions like the recent global financial crisis are transmitted to the BRICS stock markets and affect their economic growth. Moreover, international investors are especially interested in the BRICS stock markets' co-movements with these global factors, given that investment, speculation and risk diversification opportunities may arise.

More precisely, we address the following unanswered questions. Does dependence exist between each stock market of the BRICS and the influential global economic factors under consideration? Is there any symmetric or asymmetric dependence of the BRICS markets on each of the specific global factors? Has the dependence structure changed since the onset of the recent global financial crisis? Providing answers to these questions is crucial to understanding how the BRICS stock markets are becoming dependent on global stock markets and economic conditions and how this dependence has been affected by the current global financial crisis.

We study dependence using a quantile regression $(\mathrm{QR})$ approach because it allows one to examine the conditional dependence of specific quantiles of the BRICS stock returns with respect to the conditioning variables. The QR approach also provides specific insights on the impacts of the global factors on the stock market returns under different market circumstances, including bearish (lower quantile) and bullish (upper quantile) markets. QR has been previously employed in the finance literature to investigate value-at-risk (e.g., Engle and Manganelli, 2004; Rubia and Sanchis-Marco, 2013), systemic risk (e.g., Adrian and Brunnermeier, 2011) and bankruptcy prediction (e.g., Li and Miu, 2010) and to model dependence between financial variables (e.g., Bassett and Chen, 2001; Chuang et al., 2009; Baur et al., 2012; Lee and Li, 2012; Tsai, 2012; Ciner et al., 2013; Gebka and Wohar, 2013; among others). Baur 
(2013) advocates the use of the QR to study the structure and degree of dependence as it can reveal information on the asymmetric and non-linear effects of conditional variables on the dependent variables. Given that the stock prices in BRICS countries usually experience abrupt swings that could potentially change the sign and intensity of the impact of the global factors across different quantiles, in our research we adopt the flexible QR framework to evaluate the dependence between the BRICS stock markets and the global economic and financial factors. Furthermore, this QR approach is suitable to capture the additional marginal effects originating from different global factors, especially when the recent global financial crisis is considered.

Using daily data from September 1997 to September 2013, our results for the BRICS stock market dependence show that the returns of the global stock market, represented by the S\&P 500 index, have a positive and significant impact on the BRICS stock market returns before and since the onset of the current global financial crisis. Moreover, this dependence is found to be asymmetric in the tails of the return distributions where Russia, India and South Africa exhibit both upper tail dependence and lower tail independence before and since the onset of the financial crisis. On the other hand, Brazil and China show symmetric tail dependence and independence, respectively with respect to the global stock market. Overall, the BRICS stock markets co-move with the global stock market in bullish markets, while they are independent when the market is bearish, with the exception of Brazil. This evidence of tail dependence implies that BRICS stock markets are useful for international investors in bearish markets in terms of downside risk management.

The oil prices impact the BRICS stock markets in the periods before and since the onset of the global financial crisis but in different ways. Upper and lower tail independence is found for Brazil, India and China. However, since the onset of the recent financial crisis, the co-movement with the oil prices has significantly increased for all BRICS markets and all 
quantiles (with the exception of the upper tail for China and the lower tail for Russia). China has kept a control over its currency markets and inflation during bullish periods. Russia has protected its market during the financial crisis period using its oil revenues.

The dependence structure the BRICS stock markets with respect to gold is constant across quantiles, which suggests that the positive effects of gold prices on those stock returns remain almost similar regardless of the quantiles or bearish and bullish markets or in between. It also remains unaltered since the onset of the financial crisis. What this implies for the BRICS stock markets is that the role of gold as a hedge or a safe-haven asset is very limited. Two of the BRICS countries, India and China, are heavy buyers of gold but mostly as jewelry on the Main Street and not for speculation or trading purposes. The effect of the general stock market uncertainty (VIX) is asymmetric, with a significant negative impact in lower quantiles or the bearish markets but with no significant impact in the upper quantile or the bull markets (with the exception of India). This is expected since VIX reflects fear and anxiety in the market which should intensify during bearish markets. However, the impact of the stock market uncertainty (VIX) on the BRICS stock market returns dampens down since the onset of the recent financial crisis.

Finally, the impact of the U.S. economic policy uncertainty on the BRICS market returns is insignificant across different quantiles in both periods before and since the onset of the recent financial crisis. Overall, our results indicate that most of the BRICS stock markets are useful for global investors in terms of providing diversification opportunities and hedging against different influential global factors. They are especially useful for downside risk reduction purposes with respect to changes in some global factors.

The remainder of this article is organized as follows. Section 2 provides a brief literature review. Section 3 presents the econometric methodology. Section 4 describes the data and Section 5 presents and discusses the results. Finally, Section 6 provides conclusions. 


\section{Literature review}

In the literature that focuses on the performance of the emerging equity markets, Hammoudeh et al. (2013) examine the (symmetric) interrelationship between the five BRICS countries' equity market indices, and their relationship with the International Country Risk Guide (ICRG)'s three country risk rating factors (economic, financial and political), the S\&P500 index and the West Texas Intermediate (WTI) oil price. Their results show that of the five BRICS, China is the only country whose stock market responds to all of the country risk factors. In terms of the sensitivity of the country risk rating factors for the BRICs, the financial risk factor is the most sensitive followed by the economic risk factor. Hoti and McAleer (2005a; 2005b) evaluate the multivariate spillover effects of changes in four country risk ratings (economic, financial, political and composite risk) for various countries including Brazil and China, and find significant effects among these risk factors.

Ono (2011) examines the systemic impact of oil prices on the stock market returns for the four BRIC countries. He finds that increases in oil prices pull up the stock market indices for all these countries except Brazil. Lin et al. (2007) investigate the influence of domestic financial and macroeconomic factors on excess returns for eight emerging bond markets and generally figure that those local instruments can forecast the excess bond returns. For example, the domestic credit risk spread, which is the difference between the domestic corporate bond yield and the yield of the U.S. the 10-year Treasury bond of similar maturity, has a significant and positive effect on the domestic excess bond returns.

Studies that dealt with BRICS stock markets use different methods to explain the comovement or extreme comovement involving those markets. For example, Aloui et al. (2011) apply the copulas to examine the extreme financial interdependences of the BRIC emerging markets with the U.S. markets and provide strong evidence of time-varying dependence between them. This dependency is stronger for the commodity-price dependent markets 
than for the finished product export-oriented markets of the BRIC countries. Moreover, those authors observe high levels of dependence persistence for all market pairs during both bullish and bearish markets.

Using the multivariate Dynamic Conditional Correlation - Fractionally Integrated Asymmetric Power ARCH (DCC-FIAPARCH) model, Dimitriou et al. (2013) find an increasing co-movement between the BRICS and U.S. markets during the post-crisis period (from early 2009 onwards), implying that the dependence is larger in bullish than in bearish markets. This might indicate a low probability of simultaneous breakdown of the markets. Similarly, Hwang et al. (2013) examine the dynamic conditional correlations between the U.S. and ten emerging stock markets (i.e., the five BRICS markets, South Korea, Thailand, Philippines, Taiwan, and Malaysia). The authors show that different patterns of the U.S. financial crisis spillovers exist among emerging economies. They also conclude that increases in the credit TED spread (i.e., the yield difference between the three-month LIBOR rate and the U.S. three-month Treasury bills) and sovereign CDS spread, both representing higher risks, decrease the estimated conditional correlations. More importantly, increases in the foreign institutional investment, exchange market volatility, and the implied volatility (VIX) for the S\&P 500 index are found to increase the conditional correlations.

Through a novel DCC decomposing method, Zhang et al. (2013) provide strong evidence that the recent global financial crisis changes the conditional correlations between the developed (U.S. and Europe) markets and the BRICS stock markets. They also find that $70 \%$ of the BRICS stock markets' conditional correlation series demonstrate an upward long-run trend with the developed stock markets since the global crisis. Bekiros (2013) uses linear and nonlinear causal linkages to analyze the volatility spillovers among the U.S., the EU and the BRIC markets and find that the BRICs have become more internationally integrated and contagion is further substantiated since the U.S. financial crisis. 
On the other context, Piljak (2013) examines the co-movement dynamics of emerging bond markets (Brazil, China, Malaysia, Mexico, Peru, Philippines, Poland, Russia, South Africa, and Turkey) and frontier bond markets (Argentina, Bulgaria, Colombia, and Ecuador) with the U.S. government bond market and the effect of macroeconomic factors and global bond market uncertainty on the time-variations of the co-movement of these bond markets. ${ }^{1}$ The author shows that the domestic macroeconomic factors have higher relative importance than the global factors in explaining the estimated time-varying co-movement, with the domestic monetary policy and the domestic inflationary environment identified as the most influential factors. Moreover, the global bond market uncertainty is found to drive the comovement dynamics in considered markets.

Gilenko and Fedorova (2014) use the four-dimensional BEKK-GARCH-in-mean model to investigate the external (with the rest of the world) and the internal (within the group) links (spillovers) of the BRIC stock markets. ${ }^{2}$ During the pre-crisis period, they conclude that some lagged mean-to-mean spillovers between the BRIC stock markets exist and the volatility-to-volatility spillovers between these stock markets are largely present. After the crisis, the volatility-to-volatility spillovers almost disappear and the volatility-to-mean (risk premium) spillovers are not identified within any period. Furthermore, the influence of external spillovers from the developed stock markets to the rest of emerging markets is analyzed before and since the crisis. ${ }^{3}$ The authors suggest that the linkages between the developed and the emerging BRIC stock markets have significantly changed after the crisis.

\footnotetext{
${ }^{1}$ The author uses the Merrill Lynch Option Volatility Estimate MOVE Index, which is a popular measure of the government bond volatility derived from the option prices on the U.S. Treasury bonds, as a proxy for the global bond market uncertainty.

${ }^{2}$ The 4-dimensional BEKK-GARCH-in-mean model allows for the estimation of the mean-to-mean, the volatility-to-mean (risk premium) and the volatility-to-volatility spillovers.

${ }^{3}$ The MSCI (Morgan Stanley Capital International) Emerging Markets Index (EMI) is used and it refers to a free float-adjusted market capitalization weighted index that measures the equity market performance of emerging markets. It covers over 2,700 securities in 21 emerging countries including Brazil, Chile, China, Colombia, Czech Republic, Egypt, Hungary, India, Indonesia, Korea, Malaysia, Mexico, Morocco, Peru, Philippines, Poland, Russia, South Africa, Taiwan, Thailand, and Turkey. For further details, see Morgan-Stanley corporation indices.
} 
Using the quantile regression approach, Tsai (2012) finds a significant relation between stock market indices and exchange rates for six Asian countries. The negative relation between these two markets is more obvious when exchange rates are extremely high or low. Using both a multivariate regime-switching Gaussian copula model and the asymmetric generalized dynamic conditional correlation (AG-DCC) approach, Kenourgios et al. (2011) show that the emerging BRIC markets are more prone to financial contagion, while the industryspecific turmoil has a larger impact than country-specific crises.

Kang and Ratti (2013) analyze the oil shocks, the economic policy uncertainty and the stock market return linkages, and find that for the United States an unanticipated increase in the policy uncertainty has a significant negative effect on the real stock returns. Furthermore, a positive oil-market specific demand shock significantly raises the economic policy uncertainty and reduces the real stock returns.

Our study contributes to the literature by examining the impact of several important global factors on the five BRICS stock market returns, using the QR approach. Most of the extant empirical studies have examined the average influence of country risks on domestic financial markets, thus assuming a symmetric impact of changes in country risk ratings. However, our research allows for multivariate asymmetry in the relationship between the five BRICS equity market indices and with the global factors. This framework permits the effects to differ across different quantiles of the stock market returns representing different states of the markets. To that end, the QR modeling offers great flexibility and provides new insights, as they will be discussed in more details below.

\section{Econometric methodology}

A widely known measure of dependence is the correlation coefficient, which provides information on the degree of statistical relationships between the variables of interest. How- 
ever, this measure only considers symmetric linear associations between the variables and draws no distinction between dependence during up and down markets or between large and small stock price movements. Therefore, a more sophisticated tool is needed in order to capture the complex dependence between financial time series.

Since its introduction by Koenker and Bassett (1978), QR has become a popular tool in modeling dependence as it involves the consideration of a set of regression curves that differ across different quantiles of the conditional distribution of the dependent variable. ${ }^{4}$ Compared to a classical regression model, the QR functions provide a more precise and accurate result of the impact of conditional variables on the dependent variable (see, Koenker, 2005). As shown in the introduction section, QR has been used to model the dependence of financial variables and to examine the structure and degree of dependence (Chuang et al., 2009; Lee and $\mathrm{Li}, 2012$; Baur, 2013). As is the case for the copula functions, QR gives information on the average dependence as well as the upper and lower tail dependence. QR also differs from the copula functions in that it directly relates the quantile of the dependent variable with the conditioning variables. However, the copulas relate the quantiles of both the dependent and the conditioning variables.

Let $\mathrm{y}$ be a dependent variable that is assumed to be linearly dependent on $\mathrm{x}$. The $\tau^{\text {th }}$ conditional quantile function of $\mathrm{y}$ is thus specified as follows:

$$
\mathrm{Q}_{\mathrm{y}}(\tau \mid \mathrm{x})=\inf \left\{\mathrm{b} \mid \mathrm{F}_{\mathrm{y}}(\mathrm{b} \mid \mathrm{x}) \geq \tau\right\}=\sum_{\mathrm{k}} \beta_{\mathrm{k}}(\tau) \mathrm{x}_{\mathrm{k}}=\mathrm{x}^{\prime} \beta(\tau)
$$

where $\mathrm{F}_{\mathrm{y}}(\mathrm{b} \mid \mathrm{x})$ is the conditional distribution function of $\mathrm{y}$ given $\mathrm{x}$, and the $\mathrm{QR}$ coefficient $\beta(\tau)$ determines the dependence relationship between vector $\mathrm{x}$ and the $\tau^{\text {th }}$ conditional quantile of $\mathrm{y}$. Dependence is unconditional if no exogenous variables are included in $\mathrm{x}$, while it is conditional if exogenous variables are added to $\mathrm{x}$. The values of $\beta(\tau)$ for $\tau \in[0,1]$ determine the

\footnotetext{
${ }^{4}$ For further analysis of quantile regression, see Koenker (2005) and Koenker and Hallock (2001).
} 
complete dependence structure of $y$. The dependence of y based on a specific explanatory variable in vector $x$ could be: (a) constant where the values of $\beta(\tau)$ do not change for different values of $\tau$; (b) monotonically increasing (decreasing) where $\beta(\tau)$ increases (decreases) with the value of $\tau$; and (c) symmetric (asymmetric) where the value of $\beta(\tau)$ is similar (dissimilar) for low and high quantiles.

The coefficients $\beta(\tau)$ for a given $\tau$ are estimated by minimizing the weighted absolute deviations between $\mathrm{y}$ and $\mathrm{x}$ :

$$
\hat{\beta}(\tau)=\arg \min \sum_{t=1}^{T}\left(\tau-1_{\left\{y_{t}<x_{t}^{\prime} \beta(\tau)\right\}}\right)\left|y_{t}-x_{t}^{\prime} \beta(\tau)\right|
$$

where $1_{\left\{y_{\mathrm{t}}<\mathrm{x}_{\mathrm{t}}^{\prime} \beta(\tau)\right\}}$ is the usual indicator function. The solution to this problem is obtained using the linear programming algorithm suggested by Koenker and D'Orey (1987). The standard errors for the estimated coefficients can be obtained using the pairs bootstrapping procedure proposed by Buchinsky (1995) since it provides standard errors that are asymptotically valid under heteroscedasticity and misspecifications of the QR function.

In order to investigate the different effects that the conditioning variables have on the quantile function in the periods before and since the onset of the global financial crisis, we consider a QR model specified as follows:

$$
\mathrm{Q}_{\mathrm{y}}(\tau \mid \mathrm{x})=\alpha(\tau)+\sum_{\mathrm{k}} \beta_{\mathrm{k}}(\tau) \mathrm{x}_{\mathrm{k}}+\mathrm{D}\left[\gamma(\tau)+\sum_{\mathrm{k}} \theta_{\mathrm{k}}(\tau) \mathrm{x}_{\mathrm{k}}\right]
$$

where $\mathrm{D}$ is the financial crisis dummy variable that takes the value of 1 if the dependent variable is in the financial crisis subperiod and zero otherwise. The parameters $\gamma(\tau)$ and $\theta_{\mathrm{k}}(\tau)$ capture the additional marginal effects of the different conditional variables in the financial crisis subperiod for each quantile $\tau$ in comparison with the effects measured by the parameters $\alpha(\tau)$ and $\beta_{\mathrm{k}}(\tau)$ in the non-crisis subperiod. Thus, the QR model in Equation (3) allows one to examine: (a) what kind of dependence structure exists in the BRICS stock markets; (b) 
how the dependence structure is affected by different regressors; and finally, (c) how the financial crisis has affected the dependence structure and the co-movement between the BRICS stock markets and some of their global factors.

\section{Data and summary statistics}

We empirically examine the dependence structure between the BRICS stock markets and major global economic and financial factors over the daily period from September 29, 1997 to September 20, 2013. These global factors include: (i) the major global stock market represented by the S\&P 500 stock returns; (ii) the WTI crude oil price expressed in U.S. dollars per barrel, which is a global benchmark for determining the prices of other light crudes in the United States (Reboredo, 2013a); (iii) the gold price expressed in U.S. dollars per ounce; (iv) the implied volatility of the S\&P 500 index as represented by the VIX index; and (v) the U.S. economic policy uncertainty index. The choice of these global factors relies on their relevance for the performance of the BRICS stock markets. Indeed, the global stock market conditions, particularly in terms of price changes or uncertainty, affect global investor decisions regarding investment in BRICS countries which are major recipients of global investment flows. Similarly, the BRICS countries are both major world consumers of oil and gold commodities (e.g., China and India) and major world producers of commodities like oil (Brazil) and gold (South Africa), so the price movements of oil and gold commodities are expected to have important influences on stock prices in the BRICS countries. Finally, the U.S. economic policy uncertainty is a news-based economic policy index constructed from newspaper archives from the News Bank Access World News Database (see Baker et al., 2013 for more details about the construction of this index). This factor is becoming increasingly important in financial studies as a risk indicator that reflects the overall business environment and invest- 
ment profitability. Baker et al. (2013) find that an increase in the economic policy uncertainty index foreshadows a decline in economic growth and employment in the following months.

The daily data are collected from five sources. The MSCI database is used to obtain the data for the BRICS and international stock markets, the Energy Information Administration (EIA) website for the oil prices, the World Gold Council for the gold prices, Yahoo Finance for the VIX financial volatility index, and the economic policy uncertainty website for the economic policy uncertainty index..$^{5}$ The starting point of our sample period is marked by several extreme events and turbulences such as the 1997-1998 Asian crisis, the 1998 Russian crisis and the 1998 Brazilian crisis. The sample data also cover the 2001 dot-com bubble, the 2001 Argentinean economic crisis, and the 2007-2009 global financial crisis. The stock market indices for the BRICS countries are denominated in U.S. dollars. We compute the stock returns by taking the difference in the logarithm between two consecutive prices. Similarly, for all the explanatory variables, we consider the logarithmic changes in those variables.

Figure 1 shows the BRICS stock return dynamics during the sample period. We see that the stock returns are especially volatile after the mid-2008 when the global financial crisis broke. The gold and WTI price returns display a similar volatility pattern, whereas the policy uncertainty and VIX variable dynamics show no particular temporal pattern. Table 1 reports the descriptive statistics for the return series. The average stock returns are similar across the BRICS markets with the exception of China which has a negative average return. The corresponding standard deviations range from 0.021 (China) to 0.031 (Russia). The return on the S\&P 500 index is mostly equal to that of the BRICS stock markets, while oil and gold yield the highest returns. Russia's stock market presents the maximum and the minimum returns among the five BRICS markets, while the WTI crude oil market displays the maximum gain and loss returns among the commodity markets. As expected, the economic policy uncertainty

\footnotetext{
${ }^{5}$ The different websites are www.msci.com for stock markets, www.eia.gov for oil prices, www.gold.org for gold, www.policyuncertainty.com for the US economic policy uncertainty index, and finance.yahoo.com for the VIX index.
} 
and implied volatility (VIX) indices exhibit greater volatility than the other series in the sample because these indices are measures of policy risk of the economy and the stock market volatility. Negative values for skewness are common for all the stock, gold and oil returns, but are positive for the VIX and the U.S. economic policy uncertainty indices. All returns show excess kurtosis. Therefore, the Jarque-Bera test for normality strongly rejects the normality of the unconditional distributions for all the series. Finally, we test the null hypothesis of a unit root, using the conventional augmented Dickey and Fuller (1979) and Phillips and Perron (1988) statistics and the stationarity property under the null using the Kwiatkowski et al. (1992) test. The results reported in Table 1 indicate that all return series are stationary.

Given that we attempt to analyze whether the dependence between the BRICS stock market returns and the global factors changes as a result of the onset of the recent global financial crisis, we consider a dummy variable $D$ that takes the value 0 for the pre-crisis period and 1 for the crisis period and its aftermath. The crucial point here is to determine the turning point. Although several papers have considered different starting dates for the global financial crisis (e.g., Reboredo, 2012; Xu and Hamori, 2012; Ahmad et al., 2013; Dimitriou et al., 2013; Liu et al., 2013), we focus on the behavior of crude oil prices to mark the date of the financial crisis. Oil prices reached a record price of US\$145 a barrel in July 2008. Indeed, an exponential oil price growth is observed for the period January 2000 to July 2008, largely related to the high energy demand from China and other BRICS countries to support their fast economic growth. However, after the mid-July 2008 and as the global financial crisis intensified, oil prices fell rapidly and dramatically to a low of about US\$30 in December 2008, after which they started to increase again. Therefore, we set the pre-crisis break point at around the middle of July 2008, when the oil prices reached their historical maximum peak. This demarcation of the break point is also supported by the U.S. economy policy uncertainty index, which shot up during the summer meltdown that took place in August 2008. 


\section{[INSERT FIGURE 1 HERE]}

\section{[INSERT TABLE 1 HERE]}

\section{Empirical results and discussions}

Tables 2-6 report the estimates of the quantile regressions for the BRICS stock market returns. Following the $\mathrm{QR}$ literature, we show numerical results for seven quantiles from 0.05 to 0.95 with consideration of the global financial crisis. The standard errors that are obtained using a pairs bootstrapping procedure (Buchinsky, 1995) are also reported. To complement this information, Figure 2 provides the graphical results for all the quantiles and conditioning variables.

[INSERT FIGURE 2 HERE]

\subsection{Dependence structure between BRICS and the major global stock market}

Table 2 provides the results for the Brazilian market. The effect of the global major stock market as represented by the S\&P500 index is positive and significant for all quantiles of this market. The co-movement between the Brazilian stock returns and the S\&P returns intensifies from the lower to the upper quantiles, indicating that the dependence increases during the bullish market and vice versa. Indeed, the trend in correlations among the stock markets is not uniform across time when different quantiles are considered. Applying the Ftest for the equality of coefficients at low and high quantiles, the null of equality is rejected, thus confirming that the estimates for the lower and upper quantiles are statistically different. Therefore, the Brazilian and global markets display a asymmetric co-movement as the intensity of dependence increases when these markets are booming but dependence loses intensity when the markets are bearish. However, since the onset of the financial crisis, the effect of the movements in the global stock return changes, intensifying in the lower quantiles and remain- 
ing similar in the upper quantiles. Thus, during and post the financial crisis period, the structure of dependence changes and becomes almost constant along the different quantiles.

\section{[INSERT TABLE 2 HERE]}

For the Russian case (Table 3), the impact of the major global stock market is also positive and significant but only for the intermediate and upper quantiles, whereas for the lower quantiles we observe no significant effect. This implies that the structure of dependence is asymmetric, having lower tail independence and upper tail dependence. Furthermore, we do not reject the null of the equality of coefficients for the intermediate and upper quantiles. In considering the effects of the financial crisis on dependence, no significant changes in dependence are observed (except for the median), thus the structure of dependence remains unaltered.

\section{[INSERT TABLE 2 HERE]}

For the Indian stock market (Table 4), the effect of the global markets is positive and significant for the intermediate and upper quantiles with an intensity of the co-movements being similar, given that the F-test is unable to reject the null of equality. Thus, as for Russia, the structure of dependence is asymmetric, with independence in the lower tail and dependence in the upper tail. Regarding the effects of the global financial crisis on dependence, the impact of movements in the global stock index return intensifies in the intermediate quantiles but remains similar for the other quantiles. Despite this change, the structure of dependence remains similar in comparison to the pre-crisis period.

\section{[INSERT TABLE 4 HERE]}

For China (Table 5), an insignificant dependence structure with the global stock market is revealed for all quantiles except for the 0.5 and 0.75 quantiles. This evidence suggests that, in general, there is no co-movement between the Chinese stock returns and the global 
stock market index return. Despite the fact that the global financial crisis increased the stock return co-movements across the financial markets, the co-movement of Chinese stock market with the S\&P 500 remains unaltered since the onset of the global financial crisis.

\section{[INSERT TABLE 5 HERE]}

Finally, the estimation results for the South African market (Table 6) show similar results as for the Russia and Indian markets. More precisely, the South African and the global stock market exhibit asymmetric co-movement, having lower tail independence and upper tail dependence structure. In contrast, the impact of the movements in the global stock index return changes, in that it intensifies for the intermediate quantiles. However, the structure of dependence at the tails remains unaltered.

\section{[INSERT TABLE 6 HERE]}

\subsection{Dependence structure between BRICS and commodity markets}

The impact of crude oil prices on the Brazilian stock returns is positive and significant only for the intermediate quantiles, and not present for extreme quantiles (lower than 0.1 or greater than 0.95). Hence, there is tail independence, meaning that the extreme (positive or negative) oil price movements have no impact on the stock prices for this country. However, the structure of dependence changes with the onset of the global financial crisis, when greater co-movement between oil and stock prices is observed of a similar size across quantiles.

The effect of the crude oil prices on the Russian and Chinese stock returns is negligible for all quantiles except for the quantiles 0.1 to 0.5 for Russia and the quantile 0.25 for China. Hence, there is tail independence, meaning that extreme (positive or negative) oil price movements have no impact on those countries' stock returns. However, the structure of dependence changes since the onset of the global financial crisis. A greater co-movement be- 
tween the oil prices and the Russian (Chinese) stock market is observed at the intermediate (lower and intermediate) and upper quantiles in both countries.

The crude oil prices have no impact on the distribution of the Indian stock returns. However, this evidence changes since the onset of the financial crisis as the stock returns become dependent on the oil prices across different quantiles, even though the crude oil impact has a similar size across the quantiles, thus supporting the existence of a constant dependence structure. This increase in the co-movement may be explained by the high growth of the Indian economy in recent years and by greater growth dependence on oil whose prices were experiencing abrupt changes and thus affected the economic results.

The positive and significant dependence between the South African stock market returns and the oil returns is evident for all quantiles, except for the quantiles 0.1 and 0.9 , and the corresponding F-test for the equality of coefficients across those quantiles is unable to reject the null hypothesis. As a result, the dependence structure is constant across quantiles and the oil price movement has a similar impact on the quantiles of the South African stock return distribution. In addition, the co-movement increases during the subperiod since the financial crisis, even though the structure of dependence remains quite similar.

Regarding the precious metal markets, the effect of gold prices on the BRICS stock returns is positive and similar across the quantiles for the Brazilian, Indian and South African economies, with dependence remaining almost constant across different quantiles, except South Africa where the F-test for the equality of coefficients across the various quantiles is unable to reject the null hypothesis of equality. However, for Russia and China the lower tail dependence and the upper tail independence are observed. In addition, the structure of dependence does not change significantly since the onset of the financial crisis for the Brazilian, Indian and Chinese markets. However, for the Russian market, the structure of dependence changes particularly for both the intermediate and upper quantiles. Asymmetric tail depend- 
ence is observed for South Africa, even though the lower tail dependence significantly decreases with the onset of the financial crisis. This result is consistent with the role of gold as a safe haven in times of turbulent markets, and this evidence corroborates the findings of Baur and Lucey (2010) and Baur and McDermott (2010).

\subsection{Dependence structure between BRICS markets, and VIX and policy uncertainty indices}

The effect of implied volatility on the global stock market is more expected in bearish than in bullish markets. Our results indicate that this effect is significantly negative for the lower quantiles for the four BRICS markets (Brazil, South Africa, Russia and China). However, for the intermediate and upper quantiles, there is no significant impact for the VIX index on those stock returns, except for the case of Brazil. For India, the impact is only in the upper quantiles. Overall, this means that the dependence with respect to changes in the VIX is asymmetric for these BRICS. The volatility has a negative impact on the Brazilian, South African, Russian, and Chinese stock returns when they are bearish and there is more fear and volatility in the global market. However, VIX has no impact on those markets in a bullish market with the exception of that of Brazil and India. On the other hand, the structure of dependence with respect to VIX does not change since the onset of the financial crisis, with the exception of the Brazilian markets, where dependence intensifies across the different quantiles. Thus, there is strong evidence that among the BRICS, Brazil is the most sensitive to VIX.

Regarding the U.S. economic policy uncertainty index, we find insignificant dependence across different quantiles for each of the BRICS markets, with the exception of the Indian market where the impact of the economic policy uncertainty is negative and significant for lower quantiles (i.e., when the Indian market is bearish). This fact does not change since the onset of the financial crisis, except in the Indian market where dependence is also significant 
for the lower quantiles, thus confirming the presence of an asymmetric dependence structure (i.e., there are lower tail dependence and the upper tail independence).

It is worth noting that the unconditional quantiles, given by the constant term of the $\mathrm{QR}$, change with the onset of the financial crisis where the lower quantiles increase while the upper quantiles decrease, meaning that all the BRICS stock return densities move as a result of the financial crisis.

Table 7 summarizes the empirical results for the BRICS markets. All in all and in relation to our explanatory variables, the Indian stock market is not affected by the global financial crisis, except with respect to the oil prices. This is because the Indian stock market's comovement with the crude oil market emerges with the onset of the financial crisis.

\section{[INSERT TABLE 7 HERE]}

\section{Conclusion}

Modeling dependence between the global stock markets including those of the BRICS is of great importance for the market participants as the obtained results can be used to make important portfolio allocation decisions. More importantly, the stock market performance depends significantly on the changing structure of the risk factors, the business cycles, and the macroeconomic aggregate fluctuations (e.g., Fama and French, 1989; Schwert, 1990; Ferson and Harvey, 1991; Cochrane, 2008). For example, Fama and French (1989) show that the expected returns of the common stock and the long-term bonds contain a term premium that is related to business conditions. Therefore, all investors operating in the stock markets around the world give a close watch to what happens in the economy as a whole. Ultimately, there is a need to understand the dependence structure of the stock markets on the global economic and financial factors, particularly since the recent financial crisis. Various empirical methods including the multivariate GARCH class models, copulas and quantile regressions, among 
others, have been widely used to measure the co-movements. The quantile regression method appears to be the most flexible to address this research area among the cited methods as it allows one to assess the responses of a variable to the external shocks with respect to its different threshold values.

This paper contributes to the existing literature by assessing the impact of global economic and financial variables on the BRICS stock markets across different quantiles of the return distributions and over the periods before and since the onset of the recent financial crisis. The set of the global factors includes the global stock market represented by the S\&P 500 index, the oil prices, the gold prices, VIX and the U.S. economic policy uncertainty index. Our empirical evidence for the daily closing spot data from September 1997 through September 2013 reveals asymmetric dependence between the BRICS stock markets on the global stock market. This dependence does not change since the onset of the global financial crisis. As to the effects from the commodity markets, the oil prices display a symmetric independence with the BRICS markets (except South Africa), even though the dependence significantly increases since the onset of the recent financial crisis. Moreover, the gold prices co-move with the stock prices at both the upper and lower tails (except for Russia and China whose central banks bought gold heavily), and the degree of co-movement decreases since the onset of the financial crisis. Finally, the stock market uncertainty (VIX) is a relevant factor in a bear market but insignificant in a bull market for the BRICS with exception of Brazil and India. Finally, the economic policy uncertainty exerts no impact on the BRICS stock markets in both lower and upper quantiles.

Several important policy and economic implications can be drawn from the empirical results of this study. The absence of significant co-movements between the China and the global stock markets is shown in times of stress and turmoil. This implies that China, which runs a controlled economy, protects its markets during bad times. Nevertheless, given that 
China has demonstrated a very fast economic growth and plays an increasingly important role in the world economy, this link may change in the future as this country becomes more open to foreign investors and lifts controls on its market and exchange rate.

The evidence of dependence across the major global factors and the BRICS stock markets also provides meaningful insights pertinent to international asset pricing, risk management and the dynamic interactions in the global economy. The gold's ability to act as a safe haven in the case of South Africa may have financial implications regarding the presence of diversification opportunities during extreme market conditions. With the 'financialization' of the commodity markets, gold and oil can provide further protection against losses when the traditional assets (equities and bonds) experience large declines. Thus, including commodities in traditional portfolios that include the BRICS allows investors to avoid the downside risk in their investments. Gold can also provide protection against dollar devaluations (Hammoudeh et al., 2009; Reboredo, 2013b). This research is particularly helpful for portfolio risk managers, energy traders, policymakers and international investors who should be cautious about making investments in simultaneous markets that exhibit pure contagion. Cognizance of dependencies of the BRICS is crucial for policymakers to help them discern the directions of the co-movements and to safe guard the BRICS stock markets from contagion during future crises or major events. 


\section{References}

Adrian, T., Brunnermeier, M.K., 2011. COVAR. NBER, Working Paper 17454.

Ahmad, W., Sehgal, S., Bhanumurthy, N.R., 2013. Eurozone crisis and BRIICKS stock markets: Contagion or market interdependence? Economic Modelling 33, 209-225.

Aloui, R., Ben Aissa, M.S., Nguyen, D.K., 2011. Global financial crisis, extreme interdependences, and contagion effects: the role of economic structure? Journal of Banking and Finance 35, 130-141.

Baker, S.R., Bloom, N., Davis, S.J., 2013. Measuring economic policy uncertainty. Available for download from: www.PolicyUncertainty.com.

Bassett, G., Chen, H-L., 2001. Quantile style: return-based attribution using regression quantiles. Empirical Economics 26, 293-305.

Baur, D.G., 2013. The structure and degree of dependence: A quantile regression approach. Journal of Banking and Finance 37, 786-798.

Baur, D.G., Dimpfl, T., Jung, R.C., 2012. Stock return autocorrelations revisited: A quantile regression approach. Journal of Empirical Finance 19, 254-265.

Baur, D. G., McDermott, T.K., 2010. Is gold a safe haven? International evidence. Journal of Banking and Finance 34, 1886-1898.

Baur, D.G., Lucey, B., 2010. Is gold a hedge or safe haven? An analysis of stocks bonds and gold. Financial Review 45, 217-229.

Bekiros, S.D., 2013. Contagion, decoupling and the spillover effects of the US financial crisis: Evidence from the BRIC markets. International Review of Financial Analysis, http://dx.doi.org/10.1016/j.irfa.2013.07.007.

Buchinsky, M., 1995. Estimating the asymptotic covariance matrix for quantile regression models a Monte Carlo study. Journal of Econometrics 68, 303-338.

Chuang, C.-C., Kuan, C.-M., Lin, H.-Y., 2009.Causality in quantiles and dynamic stock return-volume relations. Journal of Banking and Finance 33, 1351-1360.

Ciner, C., Gurdgiev, C., Lucey, B., 2013. Hedges and safe havens: An examination of stocks, bonds, gold, oil and exchange rates. International Review of Financial Analysis 29, 202-211.

Cochrane, J., 2008. The dog that did not bark: A defense of return predictability. Review of Financial Studies 21, 1533-1575.

Dickey, D.A., Fuller, W.A., 1979. Distribution of the estimators for autoregressive time series with a unitroot. Journal of the American Statistical Society 75, 427-431.

Dimitriou, D., Kenourgios, D., Simos, T., 2013. Global financial crisis and emerging stock market contagion: A multivariate FIAPARCH-DCC approach. International Review of Financial Analysis 30, 46-56.

Engle, R.F., Manganelli, S., 2004. CAViaR: conditional autoregressive value at risk by regression quantiles. Journal of Business and Economic Statistics 22, 367-381.

Fama, E., French, K., 1990. Stock returns, expected returns, and real activity. Journal of Finance 45, 1089-1108.

Ferson, W., Harvey, C., 1991. The variation of economic risk premiums. Journal of Political Economy 99, 385415.

Gebka, B., Wohar, M.E., 2013. Causality between trading volume and returns: Evidence from quantile regressions. International Review of Economics and Finance 27, 144-159.

Gilenko, E., Fedorova, E., 2014. Internal and external spillover effects for the BRIC countries: multivariate GARCH-in-mean approach, Research in International Business and Finance, 31, 32-45.

Hammoudeh, S., Sari, R., Ewing, B., 2009. Relationships among strategic commodities and with financial variables: A new look. Contemporary Economic Policy 27, 251-264.

Hammoudeh, S., Sari, R., Uzunkaya, M. and Liu, T., 2013. The dynamics of BRICS's country risk ratings and domestic stock markets, U.S. stock market and oil price. Mathematics and Computers in Simulation 94, 277-294. 
Hoti, S., McAleer, M., 2005a. Modelling the riskiness in country risk ratings. Contributions to Economic Analysis Series 273, Amsterdam: Elsevier.

Hoti, S., McAleer, M., 2005b.Modelling spillover effects for country risk ratings and returns. Risk Letter 1, 1117.

Hwang, E., Min, H.G., Kim, B.H., Kim, H., 2013. Determinants of stock market comovements among US and emerging economies during the US financial crisis. Economic Modelling 35, 338-348.

Kang, W., Ratti, R.A., 2013. Oil shocks, policy uncertainty and stockmarket return. Journal of International Financial Markets, Institutions \& Money 26, 305- 318.

Kenourgios, D., Samitas, A., Paltalidis, N., 2011. Financial crises and stock market contagion in a multivariate time-varying asymmetric framework. Journal of International Financial Markets, Institutions \& Money 21, 92-106.

Koenker, R., 2005. Quantile Regression. Econometric Society Monograph Series, Cambridge University Press.

Koenker, R., Bassett, G., 1978. Regression quantiles. Econometrica 46(1), 33-50.

Koenker, R., D’Orey, V., 1987. Algorithm AS 229: computing regression quantiles. Journal of the Royal Statistical Society, Series C (Applied Statistics) 36(3), 383-393.

Koenker, R., Hallock, K.F., 2001. Quantile regression. Journal of Economic Perspectives 15, 143-156.

Kwiatkowski, D., Phillips, P.C.B., Schmidt, P., Shin, Y., 1992. Testing the null hypothesis of stationary against the alternative of a unit root. Journal of Econometrics 54, 159-178.

Lee, B.S., Li, M.-Y.L., 2012. Diversification and risk-adjusted performance: a quantile regression approach. Journal of Banking and Finance 36, 2157-2173.

Li, M.Y.L., Miu, P., 2010. A hybrid bankruptcy prediction model with dynamic loadings on accounting-ratiobased and market-based information: a binary quantile regression approach. Journal of Empirical Finance 17, 818-833.

Lin, C-L., Wang, M-C and Gau Y-F., Y-F., 2007. Expected risk and excess returns predictability in emerging bond markets. Applied Economics 39, 1511-1529.

Liu, T., Hammoudeh, S., Thompson, M.A., 2013. A momentum threshold model of stock prices and country risk ratings: Evidence from BRICScountries. Journal of International Financial Markets, Institutions \& Money 27, 99-112.

Ono, S., 2011 Oil price shocks and stock markets in BRICs European. Journal of Comparative Economics 8, 2945.

Phillips, P.C.B., Perron, P., 1988. Testing for a unit root in time series regressions. Biometrica 75, 335-346.

Piljak, V., 2013. Bond markets co-movement dynamics and macroeconomic factors: Evidence from emerging and frontier markets. Emerging Markets Review 17, 29-43.

Reboredo, J.C., 2012. Modelling oil price and exchange rate co-movements. Journal of Policy Modeling 34(3), 419-440.

Reboredo, J.C., 2013a. Is gold a hedge or safe haven against oil price movements? Resources Policy 38, 130137.

Reboredo, J.C., 2013b. Is gold a safe haven or a hedge for the US dollar? Implications for risk management. Journal of Banking and Finance 37, 2665-2676.

Rubia, A., Sanchis-Marco, L., 2013. On downside risk predictability through liquidity and trading activity: A dynamic quantile approach. International Journal of Forecasting 29, 202-219.

Schwert, W., 1990. Stock returns and real activity: a century of evidence. Journal of Finance 45, 1237-1257.

Tsai, I-C., 2012. The relationship between stock price index and exchange rate in Asian markets: A quantile regression approach. Journal of International Financial Markets, Institutions \& Money 22, 609-621.

Xu, H., Hamori, S., 2012. Dynamic linkages of stock prices between the BRICs and the United States: Effects of the 2008-09 financial crisis. Journal of Asian Economics 23, 344-352.

Zhang, B., Li, X., Yu, H., 2013. Has recent financial crisis changed permanently the correlations between BRICS and developed stock markets? North American Journal of Economics and Finance 26, 725- 738. 
Fig. 1. Dynamics of BRICS stock market returns and logarithmic changes in the explanatory variables

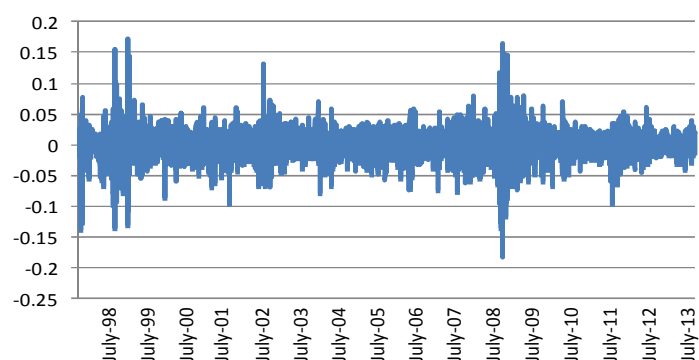

BRAZIL

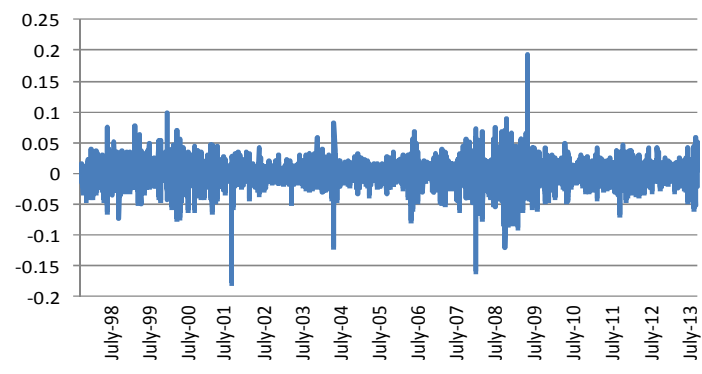

INDIA

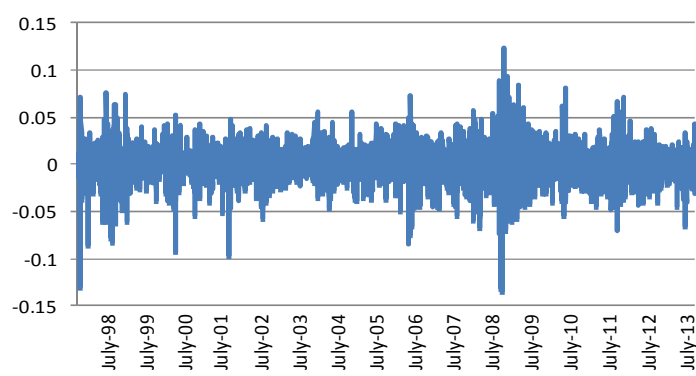

SOUTH AFRICA

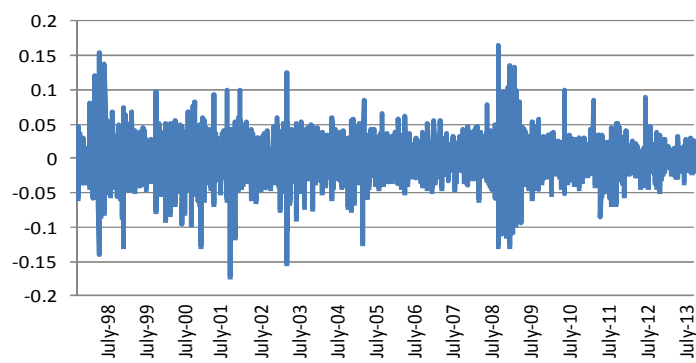

WTI

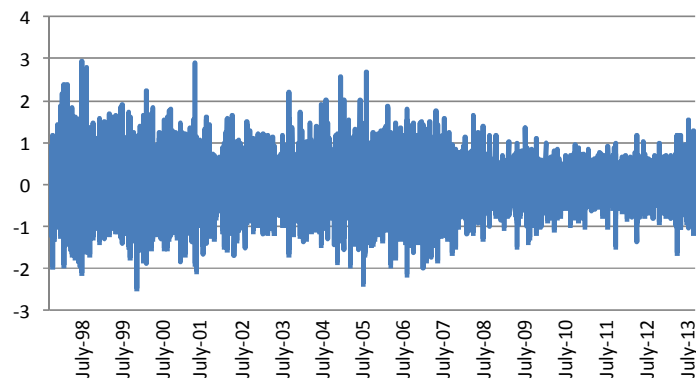

$\longrightarrow$ POLICY

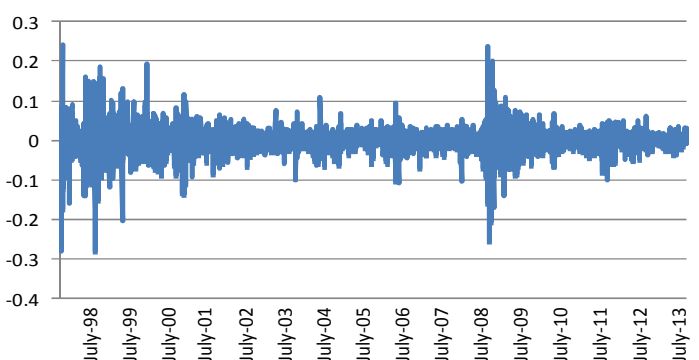

$\longrightarrow$ RUSSIA

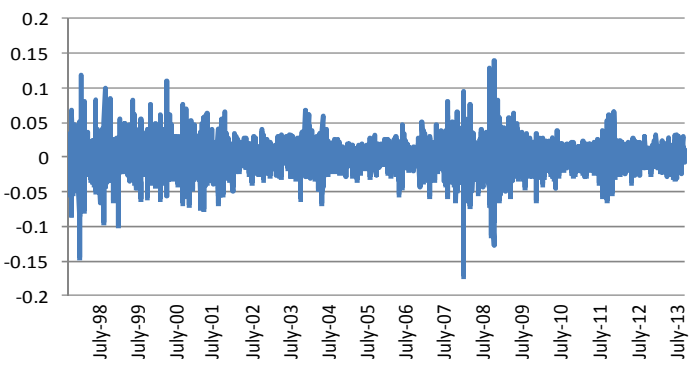

CHINA

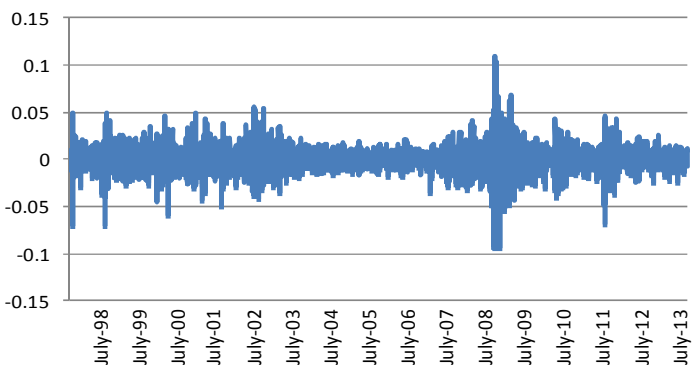

$\longrightarrow \mathrm{SP}$

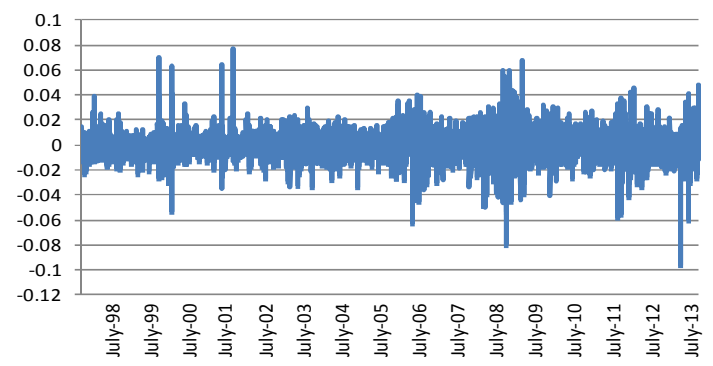

Gold

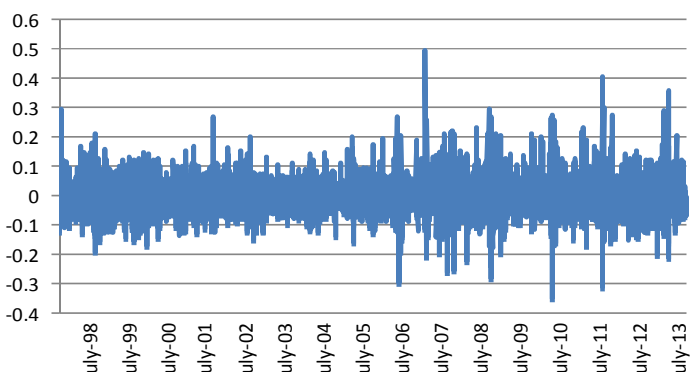

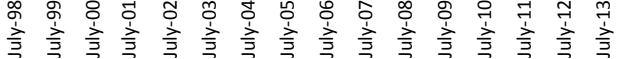


Fig. 2. Changes in the quantile regression coefficients

Panel A: Brazil
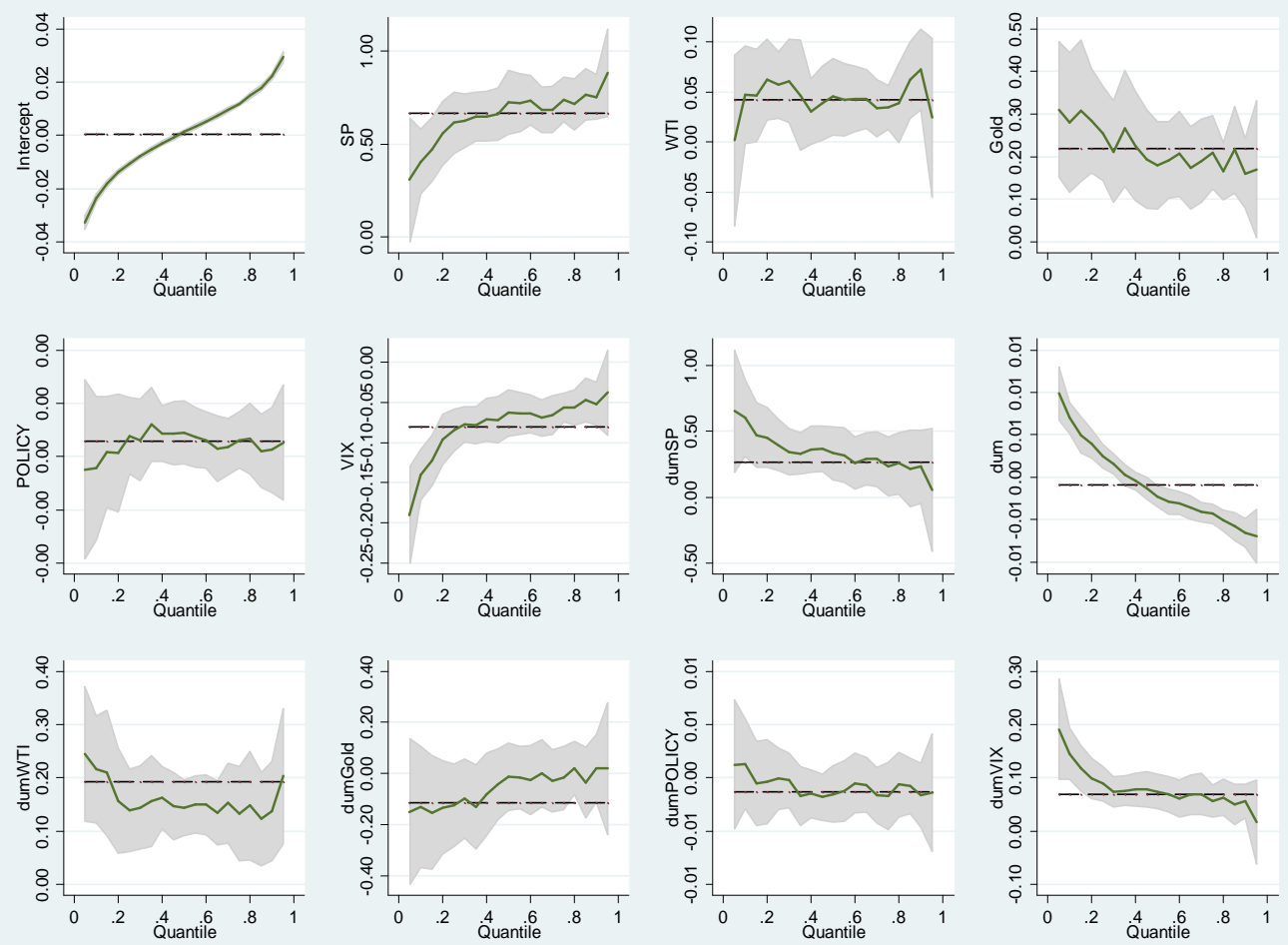

Panel B: Russia
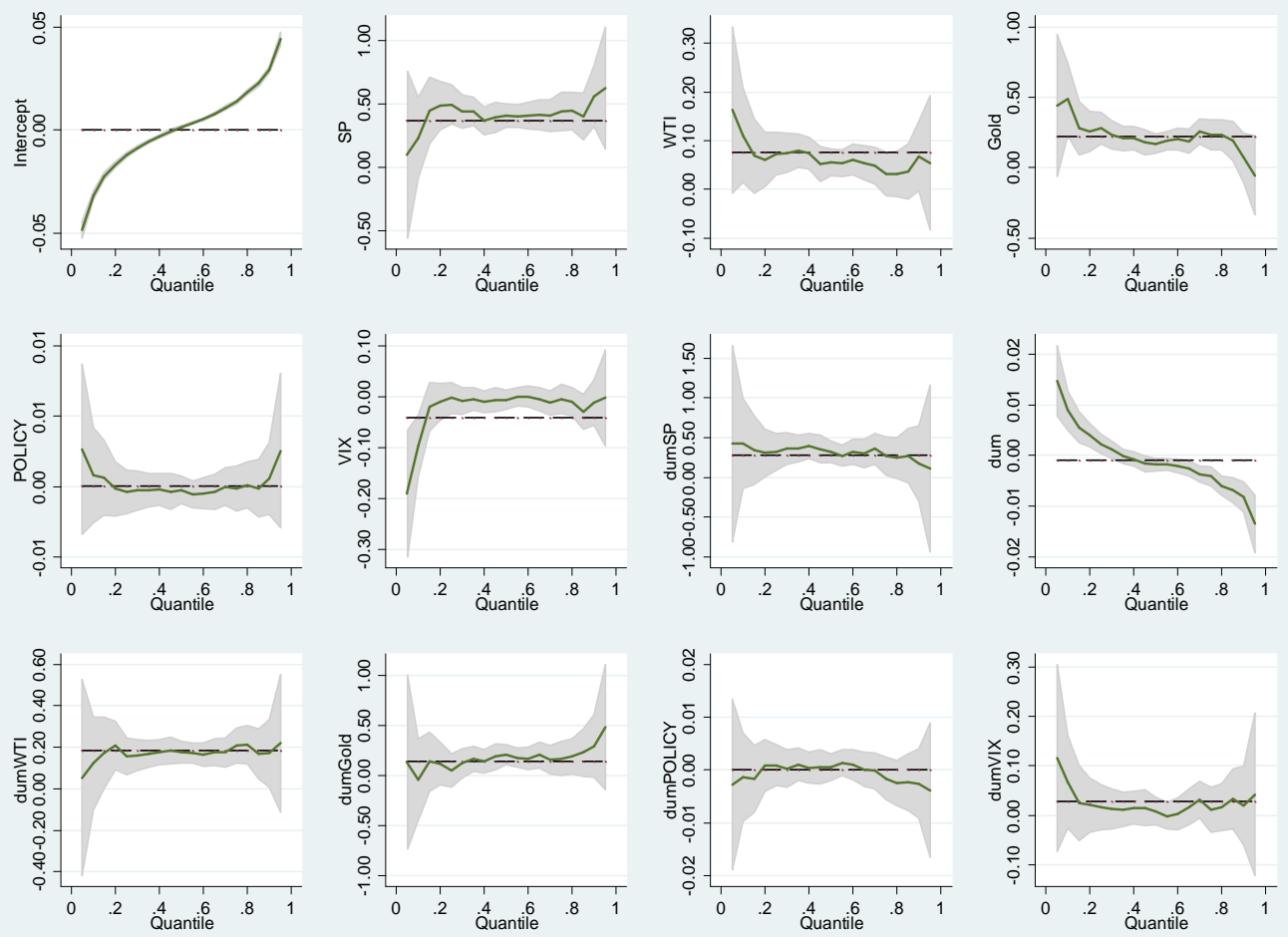
Panel C: India
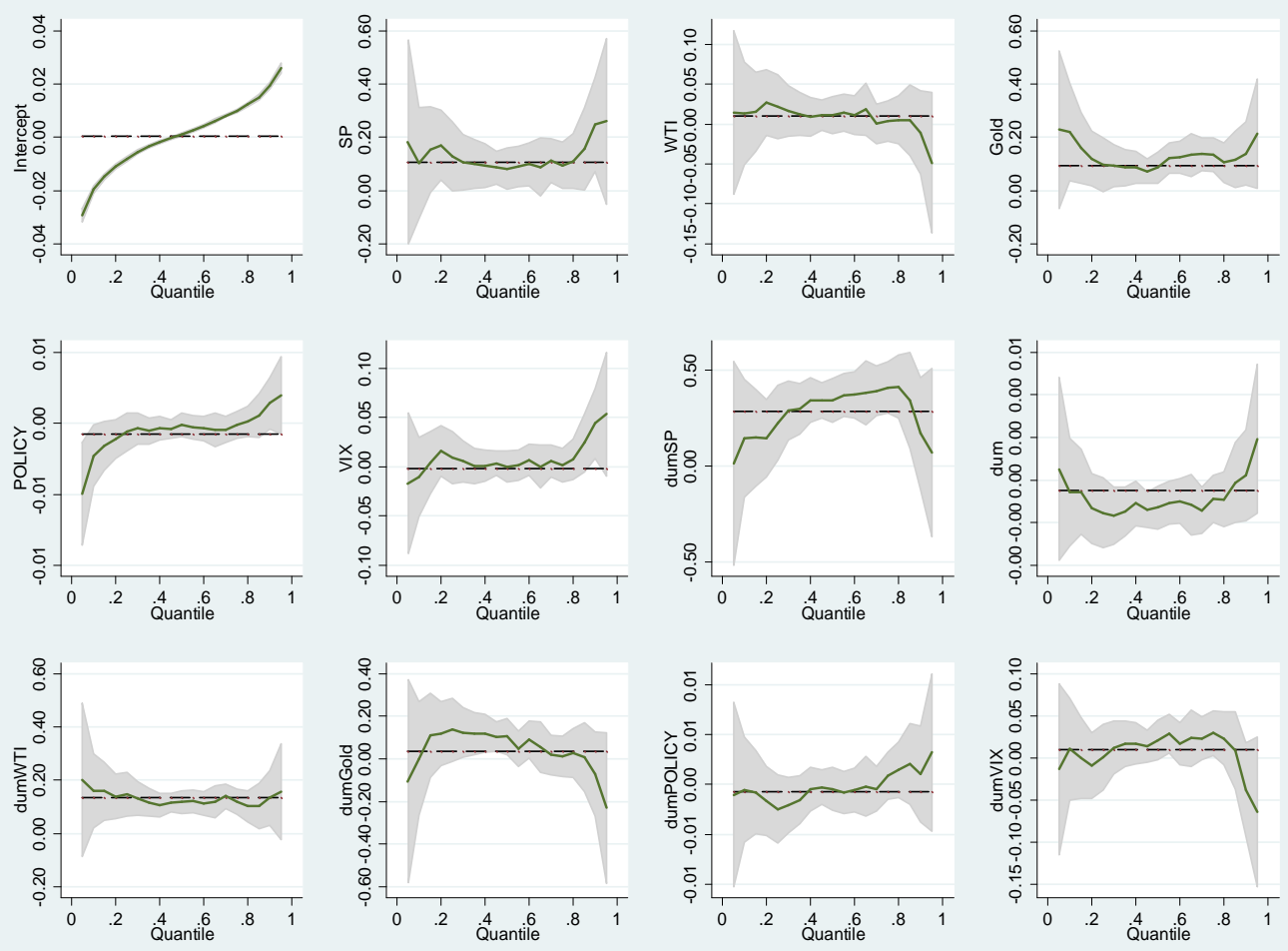

\section{Panel D: China}
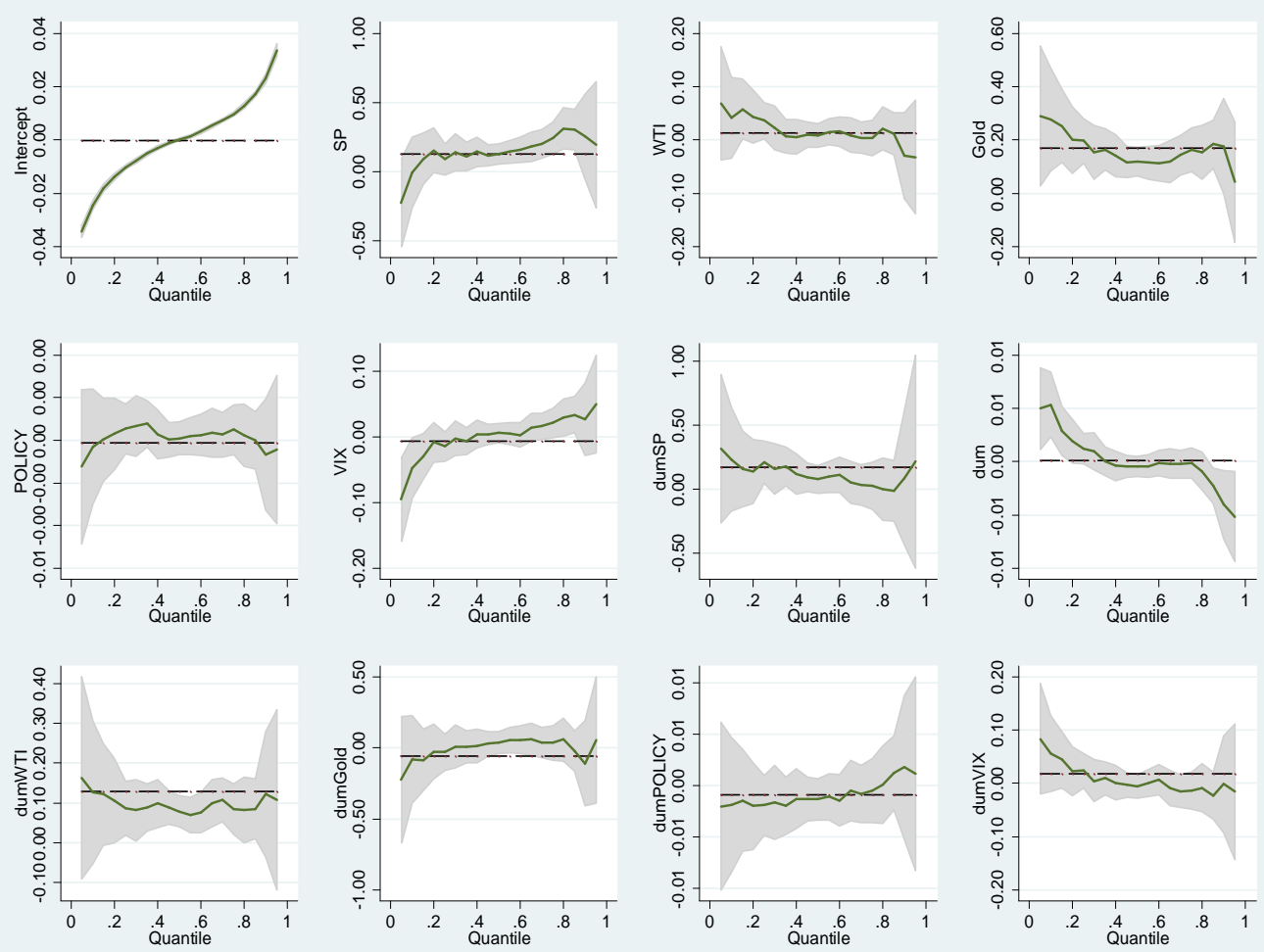
Panel E: South Africa
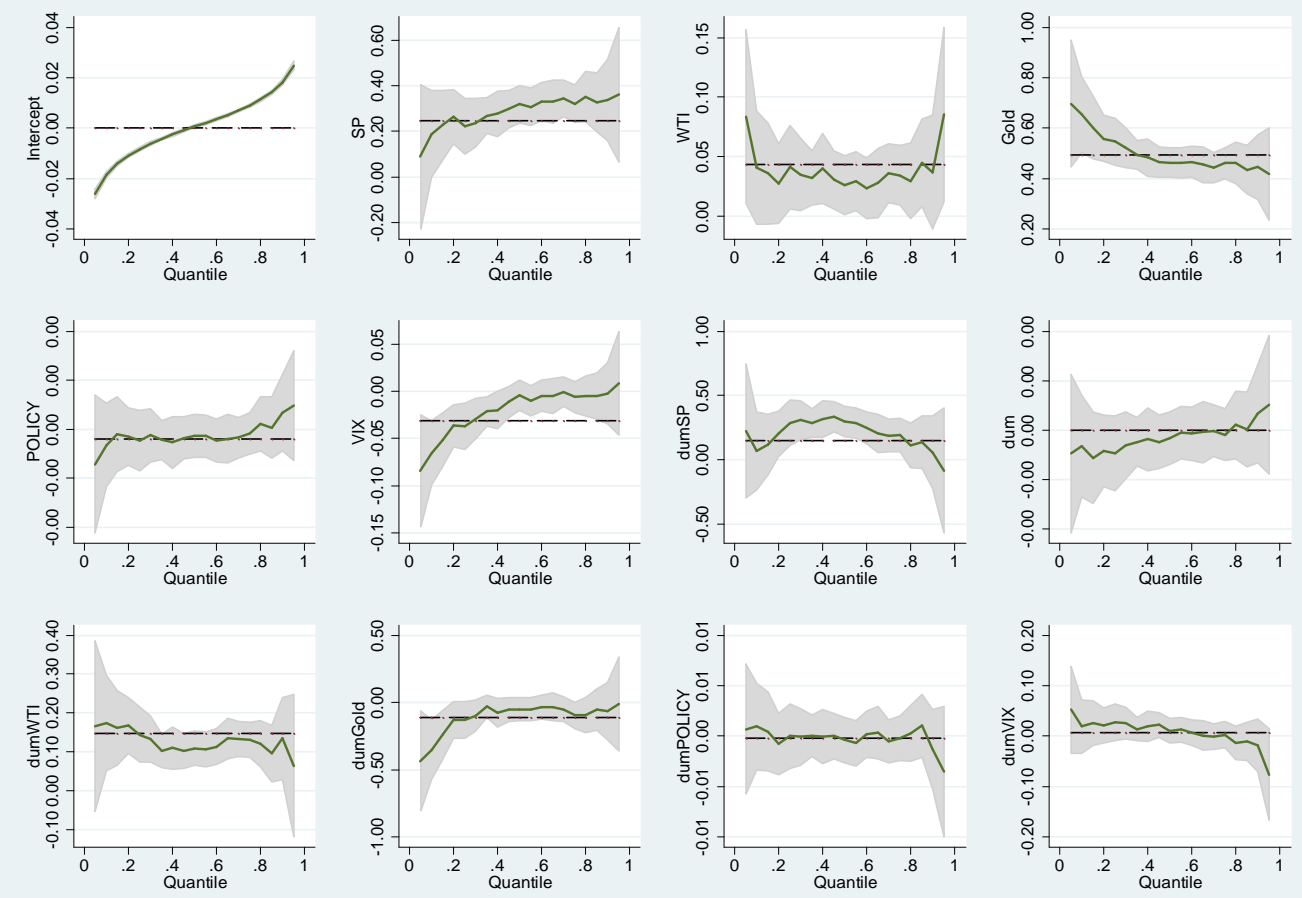
Table 1. Statistical properties for global factors (log changes) and BRICS stock returns

\begin{tabular}{|c|c|c|c|c|c|c|c|c|c|c|}
\hline & Brazil & Russia & India & China & S. Africa & S\&P 500 & WTI & Gold & Policy & VIX \\
\hline Mean $(\times 10)$ & 0.002 & 0.001 & 0.003 & -0.001 & 0.002 & 0.001 & 0.004 & 0.004 & 0.003 & -0.001 \\
\hline Std. Dev. & 0.024 & 0.031 & 0.018 & 0.021 & 0.018 & 0.013 & 0.025 & 0.011 & 0.626 & 0.063 \\
\hline Maximum & 0.173 & 0.242 & 0.194 & 0.140 & 0.123 & 0.109 & 0.164 & 0.077 & 2.946 & 0.496 \\
\hline Minimum & -0.183 & -0.281 & -0.177 & -0.171 & -0.135 & -0.094 & -0.170 & -0.096 & -2.481 & -0.351 \\
\hline Skewness & -0.177 & -0.445 & -0.356 & -0.066 & -0.425 & -0.208 & -0.159 & -0.153 & 0.130 & 0.620 \\
\hline Kurtosis & 10.015 & 14.318 & 11.729 & 8.490 & 7.663 & 10.135 & 7.793 & 9.020 & 4.063 & 6.821 \\
\hline$J B$ & $8182 *$ & $21376^{*}$ & $12720 *$ & $5002 *$ & $3726^{*}$ & $8472 *$ & $3826^{*}$ & $6026 *$ & $198^{*}$ & $2676^{*}$ \\
\hline $\mathrm{ADF}$ & $-44.6 * *$ & $-59.2 * *$ & $-59.9 * *$ & $-58.1 * *$ & $-59.4 * *$ & $-48.8^{* * *}$ & $-47.3 * *$ & $-63.2 * *$ & $-24.4 * *$ & $-30.7 * *$ \\
\hline PP & $-57.7 * *$ & $-59.2 * *$ & $-60.24 * *$ & $-58.1 * *$ & $-59.2 * *$ & $-48.8 * *$ & $-64.3 * *$ & $-63.2 * *$ & $-421.1 * *$ & $-77.1 * *$ \\
\hline KPSS & 0.158 & 0.115 & 0.093 & 0.390 & 0.097 & 0.092 & 0.037 & 0.187 & 0.022 & 0.028 \\
\hline
\end{tabular}

Notes: The data series are daily and cover the period September 29, 1997 to September 20, 2013. $J B$ is the empirical statistics of the Jarque-Bera test for normality. ADF, PP and KPSS are the empirical statistics of the Augmented Dickey-Fuller (1979) unit root test, the Phillips-Perron (1988) unit root test, and the Kwiatkowski et al. (1992) stationarity test, respectively. While the ADF and PP tests consider the null hypothesis of unit root, the Kwiatkowski et al. (1992) test examines the null of stationarity. ${ }^{*}$ and $* *$ indicate the rejection of the null hypothesis at the $5 \%$ and $1 \%$ levels, respectively. 
Table 2. Quantile regression estimates for Brazil

\begin{tabular}{|c|c|c|c|c|c|c|c|}
\hline & $\mathbf{Q}(\mathbf{0 . 0 5})$ & $Q(0.10)$ & $Q(0.25)$ & $\mathrm{Q}(\mathbf{0 . 5 0})$ & $Q(0.75)$ & $Q(0.90)$ & $Q(0.95)$ \\
\hline$\beta_{\mathrm{sp}}$ & $\begin{array}{l}0.307 * \\
(0.152)\end{array}$ & $\begin{array}{l}0.406 * \\
(0.103)\end{array}$ & $\begin{array}{l}0.614 * \\
(0.082)\end{array}$ & $\begin{array}{l}0.725 * \\
(0.078)\end{array}$ & $\begin{array}{l}0.739 * \\
(0.066)\end{array}$ & $\begin{array}{l}0.753 * \\
(0.073)\end{array}$ & $\begin{array}{l}0.883^{*} \\
(0.112)\end{array}$ \\
\hline$\theta_{\mathrm{sp}}$ & $\begin{array}{l}0.654 * \\
(0.240)\end{array}$ & $\begin{array}{l}0.603 * \\
(0.173)\end{array}$ & $\begin{array}{c}0.396^{*} \\
(0.123)\end{array}$ & $\begin{array}{l}0.334 * \\
(0.119)\end{array}$ & $\begin{array}{l}0.237 * \\
(0.124)\end{array}$ & $\begin{array}{l}0.234 * \\
(0.176)\end{array}$ & $\begin{array}{c}0.057 \\
(0.245)\end{array}$ \\
\hline$\beta_{\text {Oil }}$ & $\begin{array}{c}0.002 \\
(0.043)\end{array}$ & $\begin{array}{c}0.047 \\
(0.026)\end{array}$ & $\begin{array}{l}0.057 * \\
(0.017)\end{array}$ & $\begin{array}{c}0.045^{*} \\
(0.016)\end{array}$ & $\begin{array}{c}0.035^{*} \\
(0.015)\end{array}$ & $\begin{array}{l}0.073^{*} \\
(0.022)\end{array}$ & $\begin{array}{c}0.024 \\
(0.039)\end{array}$ \\
\hline$\theta_{\text {Oil }}$ & $\begin{array}{l}0.244 * \\
(0.066)\end{array}$ & $\begin{array}{l}0.216^{*} \\
(0.049)\end{array}$ & $\begin{array}{l}0.139 * \\
(0.039)\end{array}$ & $\begin{array}{l}0.144 * \\
(0.029)\end{array}$ & $\begin{array}{l}0.133^{*} \\
(0.041)\end{array}$ & $\begin{array}{c}0.138^{*} \\
(0.04)\end{array}$ & $\begin{array}{l}0.203^{*} \\
(0.058)\end{array}$ \\
\hline$\beta_{\text {Gold }}$ & $\begin{array}{l}0.310 * \\
(0.09)\end{array}$ & $\begin{array}{l}0.281 * \\
(0.097)\end{array}$ & $\begin{array}{c}0.255^{*} \\
(0.055)\end{array}$ & $\begin{array}{l}0.179 * \\
(0.045)\end{array}$ & $\begin{array}{c}0.210^{*} \\
(0.042)\end{array}$ & $\begin{array}{l}0.160 * \\
(0.047)\end{array}$ & $\begin{array}{l}0.170^{*} \\
(0.079)\end{array}$ \\
\hline$\theta_{\text {Gold }}$ & $\begin{array}{l}-0.149 \\
(0.144)\end{array}$ & $\begin{array}{l}-0.130 \\
(0.12)\end{array}$ & $\begin{array}{l}-0.124 \\
(0.081)\end{array}$ & $\begin{array}{l}-0.012 \\
(0.061)\end{array}$ & $\begin{array}{l}-0.017 \\
(0.064)\end{array}$ & $\begin{array}{c}0.021 \\
(0.075)\end{array}$ & $\begin{array}{c}0.020 \\
(0.127)\end{array}$ \\
\hline$\beta_{\mathrm{VIX}}$ & $\begin{array}{c}-0.190 * \\
(0.029)\end{array}$ & $\begin{array}{c}-0.140^{*} \\
(0.018)\end{array}$ & $\begin{array}{c}-0.085 * \\
(0.013)\end{array}$ & $\begin{array}{c}-0.063 * \\
(0.013)\end{array}$ & $\begin{array}{c}-0.056^{*} \\
(0.011)\end{array}$ & $\begin{array}{c}-0.052 * \\
(0.014)\end{array}$ & $\begin{array}{l}-0.038 \\
(0.025)\end{array}$ \\
\hline$\theta_{\mathrm{VIX}}$ & $\begin{array}{c}0.191 * \\
(0.04)\end{array}$ & $\begin{array}{l}0.145^{*} \\
(0.028)\end{array}$ & $\begin{array}{c}0.089 * \\
(0.018)\end{array}$ & $\begin{array}{c}0.074 * \\
(0.018)\end{array}$ & $\begin{array}{l}0.057^{*} \\
(0.019)\end{array}$ & $\begin{array}{c}0.057 * \\
(0.025)\end{array}$ & $\begin{array}{c}0.017 \\
(0.038)\end{array}$ \\
\hline$\beta_{\text {Policy }}$ & $\begin{array}{c}0.000 \\
(0.002)\end{array}$ & $\begin{array}{c}0.000 \\
(0.001)\end{array}$ & $\begin{array}{c}0.001 \\
(0.001)\end{array}$ & $\begin{array}{c}0.001 \\
(0.001)\end{array}$ & $\begin{array}{c}0.001 \\
(0.001)\end{array}$ & $\begin{array}{c}0.000 \\
(0.001)\end{array}$ & $\begin{array}{c}0.001 \\
(0.001)\end{array}$ \\
\hline$\theta_{\text {Policy }}$ & $\begin{array}{c}0.001 \\
(0.004)\end{array}$ & $\begin{array}{c}0.001 \\
(0.002)\end{array}$ & $\begin{array}{c}0.000 \\
(0.001)\end{array}$ & $\begin{array}{l}-0.002 \\
(0.001)\end{array}$ & $\begin{array}{l}-0.002 \\
(0.002)\end{array}$ & $\begin{array}{l}-0.002 \\
(0.002)\end{array}$ & $\begin{array}{l}-0.001 \\
(0.003)\end{array}$ \\
\hline$\alpha$ & $\begin{array}{c}-0.033 * \\
(0.001)\end{array}$ & $\begin{array}{c}-0.024 * \\
(0.001)\end{array}$ & $\begin{array}{c}-0.011 * \\
(0.001)\end{array}$ & $\begin{array}{l}0.001 * \\
(0.000)\end{array}$ & $\begin{array}{l}0.012 * \\
(0.001)\end{array}$ & $\begin{array}{l}0.022 * \\
(0.001)\end{array}$ & $\begin{array}{l}0.029 * \\
(0.001)\end{array}$ \\
\hline$\gamma$ & $\begin{array}{l}0.010 * \\
(0.002)\end{array}$ & $\begin{array}{l}0.007 * \\
(0.001)\end{array}$ & $\begin{array}{l}0.002 * \\
(0.001)\end{array}$ & $\begin{array}{c}-0.002 * \\
(0.001)\end{array}$ & $\begin{array}{c}-0.004 * \\
(0.001)\end{array}$ & $\begin{array}{c}-0.007 * \\
(0.001)\end{array}$ & $\begin{array}{c}-0.007 * \\
(0.002)\end{array}$ \\
\hline Pseudo $\mathrm{R}^{2}$ & 0.248 & 0.238 & 0.212 & 0.197 & 0.202 & 0.204 & 0.201 \\
\hline
\end{tabular}

Notes: This table presents the quantile regression estimates for Brazil according to the empirical model defined by Eq. (3). The numbers in parentheses are the bootstrapped standard errors. The asterisk (*) denotes statistical significance at the $5 \%$ level. 
Table 3. Quantile regression estimates for Russia

\begin{tabular}{|c|c|c|c|c|c|c|c|}
\hline & $Q(0.05)$ & $Q(0.10)$ & $Q(0.25)$ & $Q(\mathbf{0 . 5 0})$ & $Q(0.75)$ & $Q(0.90)$ & $Q(0.95)$ \\
\hline$\beta_{\mathrm{sp}}$ & $\begin{array}{l}0.099 \\
(0.349)\end{array}$ & $\begin{array}{l}0.232 \\
(0.18)\end{array}$ & $\begin{array}{l}0.497 * \\
(0.101)\end{array}$ & $\begin{array}{l}0.409^{*} \\
(0.067)\end{array}$ & $\begin{array}{l}0.442^{*} \\
(0.08)\end{array}$ & $\begin{array}{l}0.563^{*} \\
(0.152)\end{array}$ & $\begin{array}{l}0.628^{*} \\
(0.275)\end{array}$ \\
\hline$\theta_{\mathrm{sp}}$ & $\begin{array}{l}0.422 \\
(0.388)\end{array}$ & $\begin{array}{l}0.427 \\
(0.248)\end{array}$ & $\begin{array}{l}0.324 \\
(0.187)\end{array}$ & $\begin{array}{l}0.318^{*} \\
(0.147)\end{array}$ & $\begin{array}{l}0.266 \\
(0.154)\end{array}$ & $\begin{array}{l}0.178 \\
(0.189)\end{array}$ & $\begin{array}{l}0.111 \\
(0.312)\end{array}$ \\
\hline$\beta_{\text {Oil }}$ & $\begin{array}{l}0.163 \\
(0.092)\end{array}$ & $\begin{array}{l}0.111 * \\
(0.045)\end{array}$ & $\begin{array}{l}0.073^{*} \\
(0.025)\end{array}$ & $\begin{array}{l}0.056^{*} \\
(0.018)\end{array}$ & $\begin{array}{l}0.031 \\
(0.028)\end{array}$ & $\begin{array}{l}0.068 \\
(0.037)\end{array}$ & $\begin{array}{l}0.055 \\
(0.064)\end{array}$ \\
\hline$\theta_{\text {Oil }}$ & $\begin{array}{l}0.053 \\
(0.150)\end{array}$ & $\begin{array}{l}0.122 \\
(0.079)\end{array}$ & $\begin{array}{l}0.156^{*} \\
(0.057)\end{array}$ & $\begin{array}{l}0.176^{*} \\
(0.054)\end{array}$ & $\begin{array}{l}0.209 * \\
(0.055)\end{array}$ & $\begin{array}{l}0.171^{*} \\
(0.068)\end{array}$ & $\begin{array}{l}0.219^{*} \\
(0.092)\end{array}$ \\
\hline$\beta_{\text {Gold }}$ & $\begin{array}{l}0.439 * \\
(0.16)\end{array}$ & $\begin{array}{l}0.486^{*} \\
(0.145)\end{array}$ & $\begin{array}{l}0.279 * \\
(0.062)\end{array}$ & $\begin{array}{l}0.171 * \\
(0.042)\end{array}$ & $\begin{array}{l}0.233^{*} \\
(0.071)\end{array}$ & $\begin{array}{l}0.073 \\
(0.098)\end{array}$ & $\begin{array}{l}-0.055 \\
(0.151)\end{array}$ \\
\hline$\theta_{\text {Gold }}$ & $\begin{array}{l}0.133 \\
(0.233)\end{array}$ & $\begin{array}{l}-0.041 \\
(0.187)\end{array}$ & $\begin{array}{l}0.048 \\
(0.099)\end{array}$ & $\begin{array}{l}0.208 * \\
(0.080)\end{array}$ & $\begin{array}{l}0.169 \\
(0.096)\end{array}$ & $\begin{array}{l}0.292 * \\
(0.141)\end{array}$ & $\begin{array}{l}0.482^{*} \\
(0.195)\end{array}$ \\
\hline$\beta_{\mathrm{VIX}}$ & $\begin{array}{l}-0.190 * \\
(0.051)\end{array}$ & $\begin{array}{l}-0.097 * \\
(0.036)\end{array}$ & $\begin{array}{l}-0.003 \\
(0.019)\end{array}$ & $\begin{array}{l}-0.006 \\
(0.011)\end{array}$ & $\begin{array}{l}-0.005 \\
(0.015)\end{array}$ & $\begin{array}{l}-0.012 \\
(0.032)\end{array}$ & $\begin{array}{l}-0.003 \\
(0.058)\end{array}$ \\
\hline$\theta_{\mathrm{VIX}}$ & $\begin{array}{l}0.116 \\
(0.07)\end{array}$ & $\begin{array}{l}0.067 \\
(0.044)\end{array}$ & $\begin{array}{l}0.016 \\
(0.027)\end{array}$ & $\begin{array}{l}0.008 \\
(0.022)\end{array}$ & $\begin{array}{l}0.011 \\
(0.024)\end{array}$ & $\begin{array}{l}0.019 \\
(0.041)\end{array}$ & $\begin{array}{l}0.042 \\
(0.071)\end{array}$ \\
\hline$\beta_{\text {Policy }}$ & $\begin{array}{l}0.003 \\
(0.003)\end{array}$ & $\begin{array}{l}0.001 \\
(0.002)\end{array}$ & $\begin{array}{l}0.000 \\
(0.001)\end{array}$ & $\begin{array}{l}0.000 \\
(0.001)\end{array}$ & $\begin{array}{l}0.000 \\
(0.001)\end{array}$ & $\begin{array}{l}0.001 \\
(0.002)\end{array}$ & $\begin{array}{l}0.003 \\
(0.003)\end{array}$ \\
\hline$\theta_{\text {Policy }}$ & $\begin{array}{l}-0.003 \\
(0.008)\end{array}$ & $\begin{array}{l}-0.001 \\
(0.004)\end{array}$ & $\begin{array}{l}0.001 \\
(0.002)\end{array}$ & $\begin{array}{l}0.001 \\
(0.001)\end{array}$ & $\begin{array}{l}-0.002 \\
(0.002)\end{array}$ & $\begin{array}{l}-0.003 \\
(0.003)\end{array}$ & $\begin{array}{l}-0.004 \\
(0.005)\end{array}$ \\
\hline$\alpha$ & $\begin{array}{l}-0.048^{*} \\
(0.002)\end{array}$ & $\begin{array}{l}-0.032 * \\
(0.002)\end{array}$ & $\begin{array}{l}-0.012 * \\
(0.001)\end{array}$ & $\begin{array}{l}0.001 * \\
(0.000)\end{array}$ & $\begin{array}{l}0.014 * \\
(0.001)\end{array}$ & $\begin{array}{l}0.029 * \\
(0.001)\end{array}$ & $\begin{array}{l}0.044^{*} \\
(0.002)\end{array}$ \\
\hline$\gamma$ & $\begin{array}{l}0.015^{*} \\
(0.003)\end{array}$ & $\begin{array}{l}0.009 * \\
(0.002)\end{array}$ & $\begin{array}{l}0.002 * \\
(0.001)\end{array}$ & $\begin{array}{l}-0.002 * \\
(0.001)\end{array}$ & $\begin{array}{l}-0.004 * \\
(0.001)\end{array}$ & $\begin{array}{l}-0.008^{*} \\
(0.002)\end{array}$ & $\begin{array}{l}-0.013^{*} \\
(0.003)\end{array}$ \\
\hline Pseudo $\mathrm{R}^{2}$ & 0.102 & 0.094 & 0.086 & 0.077 & 0.079 & 0.078 & 0.073 \\
\hline
\end{tabular}

Notes: See the notes of Table 2. 
Table 4. Quantile regression estimates for India

\begin{tabular}{|c|c|c|c|c|c|c|c|}
\hline & $Q(0.05)$ & $Q(0.10)$ & $Q(0.25)$ & $\mathrm{Q}(\mathbf{0 . 5 0 )}$ & $Q(0.75)$ & $Q(0.90)$ & $Q(0.95)$ \\
\hline$\beta_{\mathrm{sp}}$ & $\begin{array}{l}0.183 \\
(0.180)\end{array}$ & $\begin{array}{l}0.104 \\
(0.103)\end{array}$ & $\begin{array}{l}0.128^{*} \\
(0.052)\end{array}$ & $\begin{array}{l}0.081^{*} \\
(0.041)\end{array}$ & $\begin{array}{l}0.094 \\
(0.055)\end{array}$ & $\begin{array}{l}0.248^{*} \\
(0.083)\end{array}$ & $\begin{array}{l}0.260^{*} \\
(0.123)\end{array}$ \\
\hline$\theta_{\mathrm{sp}}$ & $\begin{array}{l}0.012 \\
(0.206)\end{array}$ & $\begin{array}{l}0.143 \\
(0.139)\end{array}$ & $\begin{array}{l}0.224 * \\
(0.096)\end{array}$ & $\begin{array}{l}0.342 * \\
(0.087)\end{array}$ & $\begin{array}{l}0.409 * \\
(0.099)\end{array}$ & $\begin{array}{l}0.169 \\
(0.115)\end{array}$ & $\begin{array}{l}0.071 \\
(0.157)\end{array}$ \\
\hline$\beta_{\text {Oil }}$ & $\begin{array}{l}0.014 \\
(0.042)\end{array}$ & $\begin{array}{l}0.013 \\
(0.026)\end{array}$ & $\begin{array}{l}0.022 \\
(0.019)\end{array}$ & $\begin{array}{l}0.011 \\
(0.011)\end{array}$ & $\begin{array}{l}0.004 \\
(0.015)\end{array}$ & $\begin{array}{l}-0.011 \\
(0.026)\end{array}$ & $\begin{array}{l}-0.049 \\
(0.039)\end{array}$ \\
\hline$\theta_{\text {Oil }}$ & $\begin{array}{l}0.201^{*} \\
(0.08)\end{array}$ & $\begin{array}{l}0.160 * \\
(0.067)\end{array}$ & $\begin{array}{l}0.147 * \\
(0.034)\end{array}$ & $\begin{array}{l}0.118^{*} \\
(0.035)\end{array}$ & $\begin{array}{l}0.119 * \\
(0.041)\end{array}$ & $\begin{array}{l}0.134 * \\
(0.049)\end{array}$ & $\begin{array}{l}0.156^{*} \\
(0.076)\end{array}$ \\
\hline$\beta_{\text {Gold }}$ & $\begin{array}{l}0.228^{*} \\
(0.087)\end{array}$ & $\begin{array}{l}0.220 * \\
(0.070)\end{array}$ & $\begin{array}{l}0.096 \\
(0.055)\end{array}$ & $\begin{array}{l}0.086^{*} \\
(0.032)\end{array}$ & $\begin{array}{l}0.134 * \\
(0.033)\end{array}$ & $\begin{array}{l}0.139 * \\
(0.057)\end{array}$ & $\begin{array}{l}0.214 * \\
(0.078)\end{array}$ \\
\hline$\theta_{\text {Gold }}$ & $\begin{array}{l}-0.105 \\
(0.142)\end{array}$ & $\begin{array}{l}0.002 \\
(0.12)\end{array}$ & $\begin{array}{l}0.138 \\
(0.079)\end{array}$ & $\begin{array}{l}0.106 \\
(0.056)\end{array}$ & $\begin{array}{l}0.012 \\
(0.067)\end{array}$ & $\begin{array}{l}-0.071 \\
(0.116)\end{array}$ & $\begin{array}{l}-0.229 \\
(0.128)\end{array}$ \\
\hline$\beta_{\mathrm{VIX}}$ & $\begin{array}{l}-0.017 \\
(0.034)\end{array}$ & $\begin{array}{l}-0.010 \\
(0.019)\end{array}$ & $\begin{array}{l}0.009 \\
(0.010)\end{array}$ & $\begin{array}{l}0.000 \\
(0.009)\end{array}$ & $\begin{array}{l}0.002 \\
(0.010)\end{array}$ & $\begin{array}{l}0.044 * \\
(0.017)\end{array}$ & $\begin{array}{l}0.054 * \\
(0.023)\end{array}$ \\
\hline$\theta_{\mathrm{VIX}}$ & $\begin{array}{l}-0.013 \\
(0.042)\end{array}$ & $\begin{array}{l}0.011 \\
(0.028)\end{array}$ & $\begin{array}{l}0.001 \\
(0.017)\end{array}$ & $\begin{array}{l}0.021 \\
(0.017)\end{array}$ & $\begin{array}{l}0.029 \\
(0.017)\end{array}$ & $\begin{array}{l}-0.038 \\
(0.028)\end{array}$ & $\begin{array}{l}-0.064 \\
(0.038)\end{array}$ \\
\hline$\beta_{\text {Policy }}$ & $\begin{array}{l}-0.005^{*} \\
(0.002)\end{array}$ & $\begin{array}{l}-0.002 * \\
(0.001)\end{array}$ & $\begin{array}{l}-0.001 \\
(0.001)\end{array}$ & $\begin{array}{l}0.000 \\
(0.000)\end{array}$ & $\begin{array}{l}0.000 \\
(0.000)\end{array}$ & $\begin{array}{l}0.001 \\
(0.001)\end{array}$ & $\begin{array}{l}0.001 \\
(0.001)\end{array}$ \\
\hline$\theta_{\text {Policy }}$ & $\begin{array}{l}-0.001 \\
(0.004)\end{array}$ & $\begin{array}{l}-0.001 \\
(0.003)\end{array}$ & $\begin{array}{l}-0.002 \\
(0.002)\end{array}$ & $\begin{array}{l}0.000 \\
(0.001)\end{array}$ & $\begin{array}{l}0.001 \\
(0.002)\end{array}$ & $\begin{array}{l}0.001 \\
(0.003)\end{array}$ & $\begin{array}{l}0.003 \\
(0.004)\end{array}$ \\
\hline$\alpha$ & $\begin{array}{l}-0.029^{*} \\
(0.002)\end{array}$ & $\begin{array}{l}-0.020^{*} \\
(0.001)\end{array}$ & $\begin{array}{l}-0.008^{*} \\
(0.000)\end{array}$ & $\begin{array}{l}0.001 * \\
(0.000)\end{array}$ & $\begin{array}{l}0.010^{*} \\
(0.000)\end{array}$ & $\begin{array}{l}0.019 * \\
(0.001)\end{array}$ & $\begin{array}{l}0.026^{*} \\
(0.001)\end{array}$ \\
\hline$\gamma$ & $\begin{array}{l}0.001 \\
(0.002)\end{array}$ & $\begin{array}{l}-0.001 \\
(0.001)\end{array}$ & $\begin{array}{l}-0.002 \\
(0.002)\end{array}$ & $\begin{array}{l}-0.001 \\
(0.001)\end{array}$ & $\begin{array}{l}-0.001 \\
(0.001)\end{array}$ & $\begin{array}{l}0.000 \\
(0.001)\end{array}$ & $\begin{array}{l}0.002 \\
(0.002)\end{array}$ \\
\hline Pseudo $\mathrm{R}^{2}$ & 0.064 & 0.050 & 0.040 & 0.033 & 0.038 & 0.041 & 0.048 \\
\hline
\end{tabular}

Notes: See the notes of Table 2. 
Table 5. Quantile regression estimates for China

\begin{tabular}{|c|c|c|c|c|c|c|c|}
\hline & $Q(0.05)$ & $Q(0.10)$ & $Q(0.25)$ & $\mathrm{Q}(\mathbf{0 . 5 0 )}$ & $Q(0.75)$ & $Q(0.90)$ & $Q(0.95)$ \\
\hline$\beta_{\mathrm{sp}}$ & $\begin{array}{l}-0.223 \\
(0.132)\end{array}$ & $\begin{array}{l}-0.008 \\
(0.153)\end{array}$ & $\begin{array}{l}0.089 \\
(0.074)\end{array}$ & $\begin{array}{l}0.128^{*} \\
(0.047)\end{array}$ & $\begin{array}{l}0.244 * \\
(0.072)\end{array}$ & $\begin{array}{l}0.254 \\
(0.147)\end{array}$ & $\begin{array}{l}0.196 \\
(0.171)\end{array}$ \\
\hline$\theta_{\mathrm{sp}}$ & $\begin{array}{l}0.315 \\
(0.234)\end{array}$ & $\begin{array}{l}0.234 \\
(0.196)\end{array}$ & $\begin{array}{l}0.213 \\
(0.123)\end{array}$ & $\begin{array}{l}0.077 \\
(0.109)\end{array}$ & $\begin{array}{l}0.025 \\
(0.136)\end{array}$ & $\begin{array}{l}0.089 \\
(0.217)\end{array}$ & $\begin{array}{l}0.216 \\
(0.274)\end{array}$ \\
\hline$\beta_{\text {Oil }}$ & $\begin{array}{l}0.069 \\
(0.050)\end{array}$ & $\begin{array}{l}0.041 \\
(0.038)\end{array}$ & $\begin{array}{l}0.036^{*} \\
(0.017)\end{array}$ & $\begin{array}{l}0.008 \\
(0.012)\end{array}$ & $\begin{array}{l}0.003 \\
(0.019)\end{array}$ & $\begin{array}{l}-0.030 \\
(0.046)\end{array}$ & $\begin{array}{l}-0.032 \\
(0.042)\end{array}$ \\
\hline$\theta_{\text {Oil }}$ & $\begin{array}{l}0.163^{*} \\
(0.069)\end{array}$ & $\begin{array}{l}0.126^{*} \\
(0.052)\end{array}$ & $\begin{array}{l}0.086^{*} \\
(0.040)\end{array}$ & $\begin{array}{l}0.079 * \\
(0.040)\end{array}$ & $\begin{array}{l}0.083^{*} \\
(0.041)\end{array}$ & $\begin{array}{l}0.121 \\
(0.068)\end{array}$ & $\begin{array}{l}0.107 \\
(0.078)\end{array}$ \\
\hline$\beta_{\text {Gold }}$ & $\begin{array}{l}0.289^{*} \\
(0.14)\end{array}$ & $\begin{array}{l}0.276^{*} \\
(0.095)\end{array}$ & $\begin{array}{l}0.196^{*} \\
(0.054)\end{array}$ & $\begin{array}{l}0.118^{*} \\
(0.032)\end{array}$ & $\begin{array}{l}0.162 * \\
(0.041)\end{array}$ & $\begin{array}{l}0.176 \\
(0.097)\end{array}$ & $\begin{array}{l}0.041 \\
(0.119)\end{array}$ \\
\hline$\theta_{\text {Gold }}$ & $\begin{array}{l}-0.223 \\
(0.188)\end{array}$ & $\begin{array}{l}-0.080 \\
(0.132)\end{array}$ & $\begin{array}{l}-0.028 \\
(0.077)\end{array}$ & $\begin{array}{l}0.038 \\
(0.065)\end{array}$ & $\begin{array}{l}0.036 \\
(0.070\end{array}$ & $\begin{array}{l}-0.109 \\
(0.149)\end{array}$ & $\begin{array}{l}0.057 \\
(0.184)\end{array}$ \\
\hline$\beta_{\mathrm{VIX}}$ & $\begin{array}{l}-0.095^{*} \\
(0.035)\end{array}$ & $\begin{array}{l}-0.048 \\
(0.033)\end{array}$ & $\begin{array}{l}-0.015 \\
(0.013)\end{array}$ & $\begin{array}{l}0.006 \\
(0.008)\end{array}$ & $\begin{array}{l}0.021 \\
(0.013)\end{array}$ & $\begin{array}{l}0.026 \\
(0.026)\end{array}$ & $\begin{array}{l}0.049 \\
(0.029)\end{array}$ \\
\hline$\theta_{\mathrm{VIX}}$ & $\begin{array}{l}0.083 \\
(0.063)\end{array}$ & $\begin{array}{l}0.056 \\
(0.041)\end{array}$ & $\begin{array}{l}0.024 \\
(0.019)\end{array}$ & $\begin{array}{l}-0.005 \\
(0.016)\end{array}$ & $\begin{array}{l}-0.014 \\
(0.022)\end{array}$ & $\begin{array}{l}-0.001 \\
(0.035)\end{array}$ & $\begin{array}{l}-0.016 \\
(0.044)\end{array}$ \\
\hline$\beta_{\text {Policy }}$ & $\begin{array}{l}-0.000 \\
(0.001)\end{array}$ & $\begin{array}{l}0.000 \\
(0.001)\end{array}$ & $\begin{array}{l}0.000 \\
(0.001)\end{array}$ & $\begin{array}{l}0.000 \\
(0.000)\end{array}$ & $\begin{array}{l}0.000 \\
(0.001)\end{array}$ & $\begin{array}{l}-0.000 \\
(0.001)\end{array}$ & $\begin{array}{l}0.000 \\
(0.002)\end{array}$ \\
\hline$\theta_{\text {Policy }}$ & $\begin{array}{l}-0.002 \\
(0.004)\end{array}$ & $\begin{array}{l}-0.002 \\
(0.003)\end{array}$ & $\begin{array}{l}-0.002 \\
(0.002)\end{array}$ & $\begin{array}{l}-0.001 \\
(0.002)\end{array}$ & $\begin{array}{l}0.000 \\
(0.002)\end{array}$ & $\begin{array}{l}0.002 \\
(0.003)\end{array}$ & $\begin{array}{l}0.001 \\
(0.003)\end{array}$ \\
\hline$\alpha$ & $\begin{array}{l}-0.034 * \\
(0.001)\end{array}$ & $\begin{array}{l}-0.024 * \\
(0.001)\end{array}$ & $\begin{array}{l}-0.010^{*} \\
(0.000)\end{array}$ & $\begin{array}{l}0.000 * \\
(0.000)\end{array}$ & $\begin{array}{l}0.010^{*} \\
(0.000)\end{array}$ & $\begin{array}{l}0.023^{*} \\
(0.001)\end{array}$ & $\begin{array}{l}0.034^{*} \\
(0.001)\end{array}$ \\
\hline$\gamma$ & $\begin{array}{l}0.005^{*} \\
(0.002)\end{array}$ & $\begin{array}{l}0.005^{*} \\
(0.001)\end{array}$ & $\begin{array}{l}0.001 \\
(0.001)\end{array}$ & $\begin{array}{l}0.000 \\
(0.001)\end{array}$ & $\begin{array}{l}0.000 \\
(0.001)\end{array}$ & $\begin{array}{l}-0.004 * \\
(0.002)\end{array}$ & $\begin{array}{l}-0.005^{*} \\
(0.002)\end{array}$ \\
\hline Pseudo $\mathrm{R}^{2}$ & 0.051 & 0.038 & 0.029 & 0.015 & 0.023 & 0.017 & 0.022 \\
\hline
\end{tabular}

Notes: See the notes of Table 2. 
Table 6. Quantile regression estimates for South Africa

\begin{tabular}{|c|c|c|c|c|c|c|c|}
\hline & $Q(0.05)$ & $Q(0.10)$ & $Q(0.25)$ & $\mathrm{Q}(\mathbf{0 . 5 0 )}$ & $Q(0.75)$ & $Q(0.90)$ & $Q(0.95)$ \\
\hline$\beta_{\mathrm{sp}}$ & $\begin{array}{l}0.088 \\
(0.129)\end{array}$ & $\begin{array}{l}0.189 \\
(0.112)\end{array}$ & $\begin{array}{l}0.223^{*} \\
(0.058)\end{array}$ & $\begin{array}{l}0.319^{*} \\
(0.041)\end{array}$ & $\begin{array}{l}0.322^{*} \\
(0.059)\end{array}$ & $\begin{array}{l}0.337^{*} \\
(0.102)\end{array}$ & $\begin{array}{l}0.361^{*} \\
(0.096)\end{array}$ \\
\hline$\theta_{\mathrm{sp}}$ & $\begin{array}{l}0.221 \\
(0.224)\end{array}$ & $\begin{array}{l}0.069 \\
(0.190)\end{array}$ & $\begin{array}{l}0.287 * \\
(0.141)\end{array}$ & $\begin{array}{l}0.295 * \\
(0.075)\end{array}$ & $\begin{array}{l}0.192 * \\
(0.086)\end{array}$ & $\begin{array}{l}0.058 \\
(0.141)\end{array}$ & $\begin{array}{l}-0.084 \\
(0.176)\end{array}$ \\
\hline$\beta_{\text {Oil }}$ & $\begin{array}{l}0.084 * \\
(0.040)\end{array}$ & $\begin{array}{l}0.040 \\
(0.026)\end{array}$ & $\begin{array}{l}0.041 * \\
(0.017)\end{array}$ & $\begin{array}{l}0.026^{*} \\
(0.012)\end{array}$ & $\begin{array}{l}0.034 * \\
(0.014)\end{array}$ & $\begin{array}{l}0.037 \\
(0.024)\end{array}$ & $\begin{array}{l}0.085^{*} \\
(0.028)\end{array}$ \\
\hline$\theta_{\text {Oil }}$ & $\begin{array}{l}0.166^{*} \\
(0.069)\end{array}$ & $\begin{array}{l}0.174 * \\
(0.056)\end{array}$ & $\begin{array}{l}0.144 * \\
(0.043)\end{array}$ & $\begin{array}{l}0.109 * \\
(0.032)\end{array}$ & $\begin{array}{l}0.131^{*} \\
(0.039)\end{array}$ & $\begin{array}{l}0.134 * \\
(0.063)\end{array}$ & $\begin{array}{l}0.064 \\
(0.095)\end{array}$ \\
\hline$\beta_{\text {Gold }}$ & $\begin{array}{l}0.696^{*} \\
(0.085)\end{array}$ & $\begin{array}{l}0.653 * \\
(0.063)\end{array}$ & $\begin{array}{l}0.546^{*} \\
(0.051)\end{array}$ & $\begin{array}{l}0.463 * \\
(0.033)\end{array}$ & $\begin{array}{l}0.461^{*} \\
(0.039)\end{array}$ & $\begin{array}{l}0.445^{*} \\
(0.058)\end{array}$ & $\begin{array}{l}0.418^{*} \\
(0.061)\end{array}$ \\
\hline$\theta_{\text {Gold }}$ & $\begin{array}{l}-0.436^{*} \\
(0.144)\end{array}$ & $\begin{array}{l}-0.353 * \\
(0.101)\end{array}$ & $\begin{array}{l}-0.129 \\
(0.080)\end{array}$ & $\begin{array}{l}-0.049 \\
(0.060)\end{array}$ & $\begin{array}{l}-0.094 \\
(0.073)\end{array}$ & $\begin{array}{l}-0.064 \\
(0.086)\end{array}$ & $\begin{array}{l}-0.012 \\
(0.106)\end{array}$ \\
\hline$\beta_{\mathrm{VIX}}$ & $\begin{array}{l}-0.084 * \\
(0.023)\end{array}$ & $\begin{array}{l}-0.065^{*} \\
(0.023)\end{array}$ & $\begin{array}{l}-0.037 * \\
(0.010)\end{array}$ & $\begin{array}{l}-0.004 \\
(0.010)\end{array}$ & $\begin{array}{l}-0.006 \\
(0.011)\end{array}$ & $\begin{array}{l}-0.002 \\
(0.019)\end{array}$ & $\begin{array}{l}0.009 \\
(0.022)\end{array}$ \\
\hline$\theta_{\mathrm{VIX}}$ & $\begin{array}{l}0.052 \\
(0.039)\end{array}$ & $\begin{array}{l}0.019 \\
(0.033)\end{array}$ & $\begin{array}{l}0.027 \\
(0.020)\end{array}$ & $\begin{array}{l}0.011 \\
(0.014)\end{array}$ & $\begin{array}{l}0.003 \\
(0.017)\end{array}$ & $\begin{array}{l}-0.019 \\
(0.028)\end{array}$ & $\begin{array}{l}-0.076^{*} \\
(0.035)\end{array}$ \\
\hline$\beta_{\text {Policy }}$ & $\begin{array}{l}-0.001 \\
(0.001)\end{array}$ & $\begin{array}{l}-0.001 \\
(0.001)\end{array}$ & $\begin{array}{l}0.000 \\
(0.001)\end{array}$ & $\begin{array}{l}0.000 \\
(0.000)\end{array}$ & $\begin{array}{l}0.000 \\
(0.001)\end{array}$ & $\begin{array}{l}0.001 \\
(0.001)\end{array}$ & $\begin{array}{l}0.001 \\
(0.001)\end{array}$ \\
\hline$\theta_{\text {Policy }}$ & $\begin{array}{l}0.001 \\
(0.004)\end{array}$ & $\begin{array}{l}0.001 \\
(0.002)\end{array}$ & $\begin{array}{l}0.000 \\
(0.002)\end{array}$ & $\begin{array}{l}0.000 \\
(0.001)\end{array}$ & $\begin{array}{l}0.000 \\
(0.001)\end{array}$ & $\begin{array}{l}-0.001 \\
(0.002)\end{array}$ & $\begin{array}{l}-0.004 \\
(0.004)\end{array}$ \\
\hline$\alpha$ & $\begin{array}{l}-0.026^{*} \\
(0.001)\end{array}$ & $\begin{array}{l}-0.019^{*} \\
(0.001)\end{array}$ & $\begin{array}{l}-0.008^{*} \\
(0.000)\end{array}$ & $\begin{array}{l}0.001 * \\
(0.000)\end{array}$ & $\begin{array}{l}0.009 * \\
(0.000)\end{array}$ & $\begin{array}{l}0.018^{*} \\
(0.001)\end{array}$ & $\begin{array}{l}0.025^{*} \\
(0.001)\end{array}$ \\
\hline$\gamma$ & $\begin{array}{l}-0.001 \\
(0.002)\end{array}$ & $\begin{array}{l}-0.001 \\
(0.001)\end{array}$ & $\begin{array}{l}-0.001 \\
(0.001)\end{array}$ & $\begin{array}{l}0.000 \\
(0.001)\end{array}$ & $\begin{array}{l}0.000 \\
(0.001)\end{array}$ & $\begin{array}{l}0.001 \\
(0.001)\end{array}$ & $\begin{array}{l}0.001 \\
(0.002)\end{array}$ \\
\hline Pseudo $\mathrm{R}^{2}$ & 0.158 & 0.151 & 0.138 & 0.127 & 0.117 & 0.114 & 0.119 \\
\hline
\end{tabular}

Notes: See the notes of Table 2. 
Table 7. Summary empirical results for the BRICS

\begin{tabular}{|c|c|c|c|c|c|c|c|c|c|c|c|c|c|c|c|c|}
\hline & & \multicolumn{3}{|c|}{ Brazil } & \multicolumn{3}{|c|}{ Russia } & \multicolumn{3}{|c|}{ India } & \multicolumn{3}{|c|}{ China } & \multicolumn{3}{|c|}{ S. Africa } \\
\hline & & $\mathrm{L}$ & $\mathrm{M}$ & $\mathrm{H}$ & $\mathrm{L}$ & $\mathrm{M}$ & $\mathrm{H}$ & $\mathrm{L}$ & $\mathrm{M}$ & $\mathrm{H}$ & $\mathrm{L}$ & $\mathrm{M}$ & $\mathrm{H}$ & $\mathrm{L}$ & $\mathrm{M}$ & $\mathrm{H}$ \\
\hline \multirow[t]{2}{*}{ S\&P500 } & (1) & + & + & + & NS & + & + & $\mathrm{NS}$ & + & + & NS & + & NS & NS & + & + \\
\hline & (2) & + & + & + & $\mathrm{NS}$ & + & $\mathrm{NS}$ & NS & + & $\mathrm{NS}$ & $\mathrm{NS}$ & $\mathrm{NS}$ & NS & $\mathrm{NS}$ & + & $\mathrm{NS}$ \\
\hline \multirow[t]{2}{*}{ Oil } & (1) & $\mathrm{NS}$ & + & NS & NS & + & NS & NS & NS & NS & NS & $\mathrm{NS}$ & NS & + & + & + \\
\hline & (2) & + & + & + & NS & + & + & + & + & + & + & + & NS & + & + & + \\
\hline \multirow[t]{2}{*}{ Gold } & (1) & + & + & + & + & + & NS & + & + & + & + & + & NS & + & + & + \\
\hline & (2) & $\mathrm{NS}$ & NS & $\mathrm{NS}$ & NS & NS & + & $\mathrm{NS}$ & $\mathrm{NS}$ & $\mathrm{NS}$ & $\mathrm{NS}$ & $\mathrm{NS}$ & $\mathrm{NS}$ & + & NS & $\mathrm{NS}$ \\
\hline \multirow[t]{2}{*}{ VIX } & (1) & - & - & NS & - & NS & NS & NS & NS & + & + & $\mathrm{NS}$ & NS & - & NS & $\mathrm{NS}$ \\
\hline & (2) & + & + & NS & NS & NS & NS & NS & NS & NS & NS & NS & NS & NS & NS & - \\
\hline \multirow[t]{2}{*}{ EPUI } & (1) & $\mathrm{NS}$ & $\mathrm{NS}$ & $\mathrm{NS}$ & $\mathrm{NS}$ & $\mathrm{NS}$ & $\mathrm{NS}$ & + & $\mathrm{NS}$ & $\mathrm{NS}$ & $\mathrm{NS}$ & $\mathrm{NS}$ & $\mathrm{NS}$ & $\mathrm{NS}$ & $\mathrm{NS}$ & $\mathrm{NS}$ \\
\hline & (2) & NS & NS & NS & $\mathrm{NS}$ & NS & NS & $\mathrm{NS}$ & $\mathrm{NS}$ & NS & $\mathrm{NS}$ & $\mathrm{NS}$ & $\mathrm{NS}$ & $\mathrm{NS}$ & $\mathrm{NS}$ & $\mathrm{NS}$ \\
\hline
\end{tabular}

Notes: L, M and $\mathrm{H}$ represent low quantile, medium quantile and high quantile, respectively. NS means no significant dependence while $+(-)$ indicates positive (negative) and statistically significant co-movement. (1) and (2) represent model without and with recent financial crisis variable, respectively. EPUI denotes the US economic policy uncertainty index. 